\title{
Biotechnological Transformation of Lignocellulosic Biomass in to Industrial Products: An Overview
}

\author{
Amit Kumar*, Archana Gautam, Dharm Dutt \\ Department of Paper Technology, Indian Institute of Technology Roorkee, Saharanpur Campus, Saharanpur, \\ India \\ Email: "baliyaniitr@gmail.com
}

Received 15 January 2016; accepted 15 March 2016; published 18 March 2016

Copyright (C) 2016 by authors and Scientific Research Publishing Inc.

This work is licensed under the Creative Commons Attribution International License (CC BY). http://creativecommons.org/licenses/by/4.0/

(c) (i) Open Access

\begin{abstract}
Lignocellulose - a major component of biomass available on earth is a renewable and abundantly available with great potential for bioconversion to value-added bio-products. The review aims at physio-chemical features of lignocellulosic biomass and composition of different lignocellulosic materials. This work is an overview about the conversion of lignocellulosic biomass into bio-energy products such as bio-ethanol, 1-butanol, bio-methane, bio-hydrogen, organic acids including citric acid, succinic acid and lactic acid, microbial polysaccharides, single cell protein and xylitol. The biotechnological aspect of bio-transformation of lignocelluloses research and its future prospects are also discussed.
\end{abstract}

\section{Keywords}

Lignocellulosic Biomass, Bio-Transformation, Bio-Energy, Organic Acids, Microbial Polysaccharides, Single Cell Proteins

\section{Introduction}

The amount of solar energy received on earth's surface is $2.5 \times 10^{21}$ Btu/year ( $1 \mathrm{Btu}=55.05585$ Joules $)$, more than 12,000 times the present human requirement of $2.0 \times 10^{17}$ Btu/year, and approximately the projected demand of energy in 2050 would be about 4000 times [1] [2]. The solar energy, stored as carbon via photosynthesis is 10 times the world usage. Throughout the world, terrestrial plants produce $1.3 \times 10^{10}$ metric tons (dry weight basis) of wood per year, which has the energetic equivalent of $7 \times 10^{9}$ metric tons of coal or about

${ }^{*}$ Corresponding author.

How to cite this paper: Kumar, A., Gautam, A. and Dutt, D. (2016) Biotechnological Transformation of Lignocellulosic Biomass in to Industrial Products: An Overview. Advances in Bioscience and Biotechnology, 7, 149-168. 
two-third of world's energy requirement. Available cellulosic feedstocks from agriculture and other sources are about 180 million tons per year [1] [2]. Lignocellulose is the major component of biomass, consisting of around half of the plant matter produced by photosynthesis and it is the most abundant renewable organic resource in soil. It consists of cellulose, hemicelluloses and lignin that are strongly intermeshed and chemically bonded by covalent linkages and non-covalent forces [3] [4]. The chemical properties of components of lignocellulosic materials make them suitable substrate of enormous biotechnological values [5] [6]. Large amounts of lignocellulosic materials are generated through forestry and agricultural practices, timber, pulp and paper, and many agro-industries and they generate an environmental pollution problem. A large fraction of these lignocellulosic materials is often disposed of by burning, which is not restricted to developing countries alone, but is considered as a global phenomenon [5] [7]. However, the huge amount of residual plant biomass considered as "waste" can potentially be converted into different value-added products such as bio-ethanol, bio-methane, and other value added products. These lignocellulosic wastes can also be used as energy sources for microorganism during fermentation to produce various lignocellulolytic enzymes [5].

\section{Lignocellulosic Biomass}

Lignocellulosic biomass is a major component of plants that provides them structure and is usually present in stalks, leaves and roots. Lignocellulosic biomass consists mainly of three types of polymers: Cellulose (30\% $60 \%)$, hemicelluloses (20\% - 40\%) and lignin (10\% - 25\%) which are interlinked to each other in a hetero-matrix. Approximately $90 \%$ of dry matter in lignocellulosics consists of cellulose, hemicelluloses and lignin, whereas the rest comprises of ash and extractives [8]-[11]. The relative abundance of cellulose, hemicelluloses and lignin depends on type of biomass and vary in different lignocellulosic biomass (Table 1) [3] [5] [6] [10] [12]-[27]. Composition of lignocellulosic biomass is influenced by the plant's genetic and environmental factors that vary considerably [6] [8] [10].

Cellulose $\left(\mathrm{C}_{6} \mathrm{H}_{10} \mathrm{O}_{5}\right)_{n}$ is a homopolysaccharide composed of linear chains of $\beta$-D-glucose units linked by $\beta$ - 1 , 4 glycosidic linkage. These chains are linked by strong hydrogen bonding which forms the cellulose chains into microfibrils, making it crystalline in nature. These microfibrils are bundled together to form cellulose fibres. Cellulose consists of crystalline (organized) region which is resistant to degradation and amorphous (not well organized) region which is easy to degrade [28]-[30]. The cellulose fibres are embedded in an amorphous matrix of hemicelluloses, lignin and pectin. Lignin and hemicellulose are present in the space between cellulose microfibrils in primary and secondary cell walls and middle lamellae [31] [32].

Hemicelluloses are the branched heteropolymers consisting of pentose sugars (D-xylose and L-arabinose) and hexose sugars (D-mannose, D-glucose and D-galactose) with xylose being most abundant [1] [33]. Hemicelluloses are composed of xylan, mannan, arabinan and galactan as main heteropolymer [34]. Xylan is the major structural component of the plant hemicelluloses and it is the second most abundant renewable polysaccharide in nature after cellulose. Xylan represents approximately one-third of all the renewable organic carbon on earth [35] [36]. Xylan is a complex polysaccharide consisting of a backbone of xylose residues connected by $\beta$-1, 4-glycosidic linkage along with traces of L-arabinose [34] [37]. The xylan layer with its covalent interaction to lignin and its non-covalent linkage with cellulose may be essential in maintaining the integrity of cellulose in situ and in protecting the cellulosic fibers against degradation to cellulases [34] [38].

Lignin is an aromatic polymer, consisting of phenyl propane units which are organized in to a large three dimensional network structure. The phenyl propane unit's p-coumaryl alcohol, coniferyl alcohol, and sinapyl alcohol are joined by $\mathrm{C}-\mathrm{O}-\mathrm{C}$ and $\mathrm{C}-\mathrm{C}$ linkages. Lignin also contains methoxyl, phenolic, hydroxyl and terminal aldehyde groups in the side chains. Lignin acts as glue and fills up the gap between and around cellulose and hemicelluloses in lignocellulosic biomass which binds them tightly. Lignin is an amorphous heteropolymer which makes the cell wall impermeable, resistant against microbial and oxidative attack [3] [8] [39] [40]. Generally, softwoods have higher lignin content compared to hardwoods while higher amount of holocellulose is present in hardwoods. The presence of lignin in lignocellulosic biomass makes difficult the release of monomer sugars from holocellulose [8].

Extractives are low molecular weight and non-structural components of lignocellulosic biomass which are soluble in neutral organic solvents or water. Extractives consist of biopolymers such as terpenoids, steroids, resin acids, lipids, waxes, fats, and phenolic constituents in the form of stilbenes, flavanoids, tannins, and lignans. Generally, percentage of extractives is higher in leaves, roots and bark compared to steam wood [8] [41] [42]. The inorganic matter in lignocellulosic biomass is regarded as ash content which consists of major elements (Si, 
Table 1. Composition of different lignocellulosic biomass.

\begin{tabular}{|c|c|c|c|c|}
\hline Lignocellulosic material & Lignin (\%) & Hemicellulose (\%) & Cellulose (\%) & References \\
\hline Bamboo & $21-31$ & $15-26$ & $26-43$ & [3] [16] \\
\hline Banana waste & 14 & 14.8 & 13.2 & [3] \\
\hline Barley straw & $14-15$ & $24-29$ & $31-34$ & [15] [16] \\
\hline Bast fibre jute & $21-26$ & $18-21$ & $45-53$ & [3] [16] \\
\hline Bast fibre kenaf & $15-19$ & $22-23$ & $31-39$ & [3] [16] \\
\hline Black gram residue & 23.14 & 32.48 & 26.80 & [17] \\
\hline \multirow{2}{*}{ Coastal Bermuda grass } & 6.4 & 35.7 & 25 & [5] [18] \\
\hline & 19.4 & 13.3 & 47.8 & {$[14]$} \\
\hline Coconut coir & 18 & 26 & 48 & [19] \\
\hline \multirow{2}{*}{ Corn cob } & 15 & 35 & 45 & [3] [5] [18] \\
\hline & $4.5-6.6$ & $38-42$ & 35 & {$[13]$} \\
\hline Corn stalks & 17 & 24 & 43 & [19] \\
\hline \multirow{2}{*}{ Corn stover } & 18 & 22 & 40 & [20] \\
\hline & 18 & 20.5 & 41.7 & [21] \\
\hline Cotton gin waste & - & 16 & 78 & [19] \\
\hline Elephant grass & 24 & 24 & 22 & {$[3]$} \\
\hline Esparto grass & $17-19$ & $27-32$ & $33-38$ & [3] [16] \\
\hline Flax straw & 22 & 27 & 29 & {$[15]$} \\
\hline Grasses (average) & $10-30$ & $25-50$ & $25-40$ & {$[6]$} \\
\hline Hardwood stem & $18-25$ & $24-40$ & $40-55$ & [3] [5] [6] [18] \\
\hline Leaves & 0 & $80-85$ & $15-20$ & [5] [18] \\
\hline Millet husk & 14 & 27 & 33 & [19] \\
\hline Newspaper & $18-30$ & $25-40$ & $40-55$ & [5] [18] \\
\hline Nut shells & $30-40$ & $25-30$ & $25-30$ & [5] [18] \\
\hline Oat straw & $16-19$ & $27-38$ & $31-37$ & [3] [16] \\
\hline $\begin{array}{l}\text { Orchard grass (medium } \\
\text { maturity) }\end{array}$ & 4.7 & 40 & 32 & [3] [5] \\
\hline Pinewood & 20 & 24 & 39 & {$[10]$} \\
\hline Poplar wood & 26 & 17 & 35 & {$[22]$} \\
\hline Rice husk & 14 & 24 & 31 & [19] \\
\hline Rice straw & 18 & 24 & 32.1 & [3] [5] [14] [18] \\
\hline Rye straw & $16-19$ & $27-30$ & $33-35$ & [3] [16] \\
\hline Sabai grass & 20.88 & 23.72 & 49.90 & {$[23]$} \\
\hline Softwood stem & $25-35$ & $25-35$ & $45-50$ & [3] [5] [6] \\
\hline \multirow{3}{*}{ Sugarcane bagasse } & $19-24$ & $27-32$ & $32-44$ & [16] [19] \\
\hline & 18.4 & 26.9 & 38.1 & [24] \\
\hline & 24 & 25 & 43 & {$[21]$} \\
\hline Sugarcane tops & 36.1 & 24.2 & 33.3 & {$[25]$} \\
\hline Sunhemp residue & $17.4-18.4$ & $11.9-13$ & $43.4-48$ & {$[26]$} \\
\hline Sweet sorghum bagasse & 18 & 25 & 45 & {$[22]$} \\
\hline \multirow{2}{*}{ Switchgrass } & 12 & 31 & 45 & [3] \\
\hline & 18 & 22 & 31 & {$[21]$} \\
\hline Timothy grass & 18 & 30 & 34 & {$[10]$} \\
\hline $\begin{array}{l}\text { Waste papers from chemical } \\
\text { pulps }\end{array}$ & $5-10$ & $10-20$ & $60-70$ & [5] [18] \\
\hline \multirow[t]{3}{*}{ Wheat bran } & $3-10$ & $22-25$ & $7-11$ & {$[27]$} \\
\hline & $16-21$ & $26-32$ & $29-35$ & [5] \\
\hline & 7.7 & 30.8 & 41.3 & {$[12]$} \\
\hline \multirow[t]{3}{*}{ Wheat straw } & 15 & 50 & 30 & [5] \\
\hline & 17 & 23 & 33 & {$[21]$} \\
\hline & 14.5 & 24.8 & 36 & [24] \\
\hline
\end{tabular}


$\mathrm{Na}, \mathrm{K}, \mathrm{Mg}$ and $\mathrm{Ca}$ ) and minor elements (Al, Fe, Mn, P and S). Ash content in dry wood and shells is less than $1 \%$ (wt/wt) while it may be up to $25 \%$ in straws and husks [8] [41] [42].

\section{Biotransformation of Lignocellulosic Biomass}

Lignocellulosic biomass from wood, grasses, crop residues, forestry waste, and municipal solid waste are particularly abundant in nature and have a potential for bioconversion into various value added biological and chemical products. Accumulation of lignocellulosic biomass in large quantities presents a disposal problem which results not only in deterioration of environment but also loss of valuable materials. This lignocellulosic biomass can be used in paper manufacture, animal feed, biomass fuel production, and composting [3]. Biotechnological transformation of lignocellulosic biomass can make significant contribution for the production of organic chemicals. Over $75 \%$ of organic chemicals are synthesized from five primary base chemicals which are ethylene, propylene, toluene, xylene and benzene [5] [43]. These lignocellulosic biomass resources can also be used to produce various organic chemicals such as ethanol [44] [45], acetone [46] [47], butanol [46] [48], bio-hydrogen [49] [50], bio-methane [51]-[53], acetic acid [54] [55], citric acid [56] [57], fumaric acid [58], lactic acid [59], xylitol [60] etc. Aromatic compounds might be produced from lignin whereas the low molecular weight aliphatic compounds can be derived from ethanol produced by fermentation of sugars (glucose, mannose and xylose) generated from saccharification of lignocellulosic biomass [5]. Biotechnological conversion of lignocellulosic biomass in various industrial products is cost effective and environmentally sustainable route.

\section{Pretreatment and Hydrolysis of Lignocellulosic Biomass}

Solid-state and submerged fermentation conditions have been used for the production of compounds of industrial interest from lignocellulosic biomass. In solid-state fermentation (SSF), lignocellulosic biomass is utilized directly without any pretreatment or after some physical, chemical, or biological pretreatments. Lignocellulosic biomass are recalcitrant against enzymatic attack therefore, a pretreatment step is required which makes lignocellulosic biomass suitable for fermentation. Lignocellulosic biomass-derived sugars are economically attractive feedstock for large scale fermentation of different chemicals. Sugars released after hydrolysis of cellulose and hemicelluloses are converted into different industrial products like ethanol, butanol, glycerol, organic acids, bioactive polysaccharides, and others through submerged fermentation (Figure 1) [40] [61].

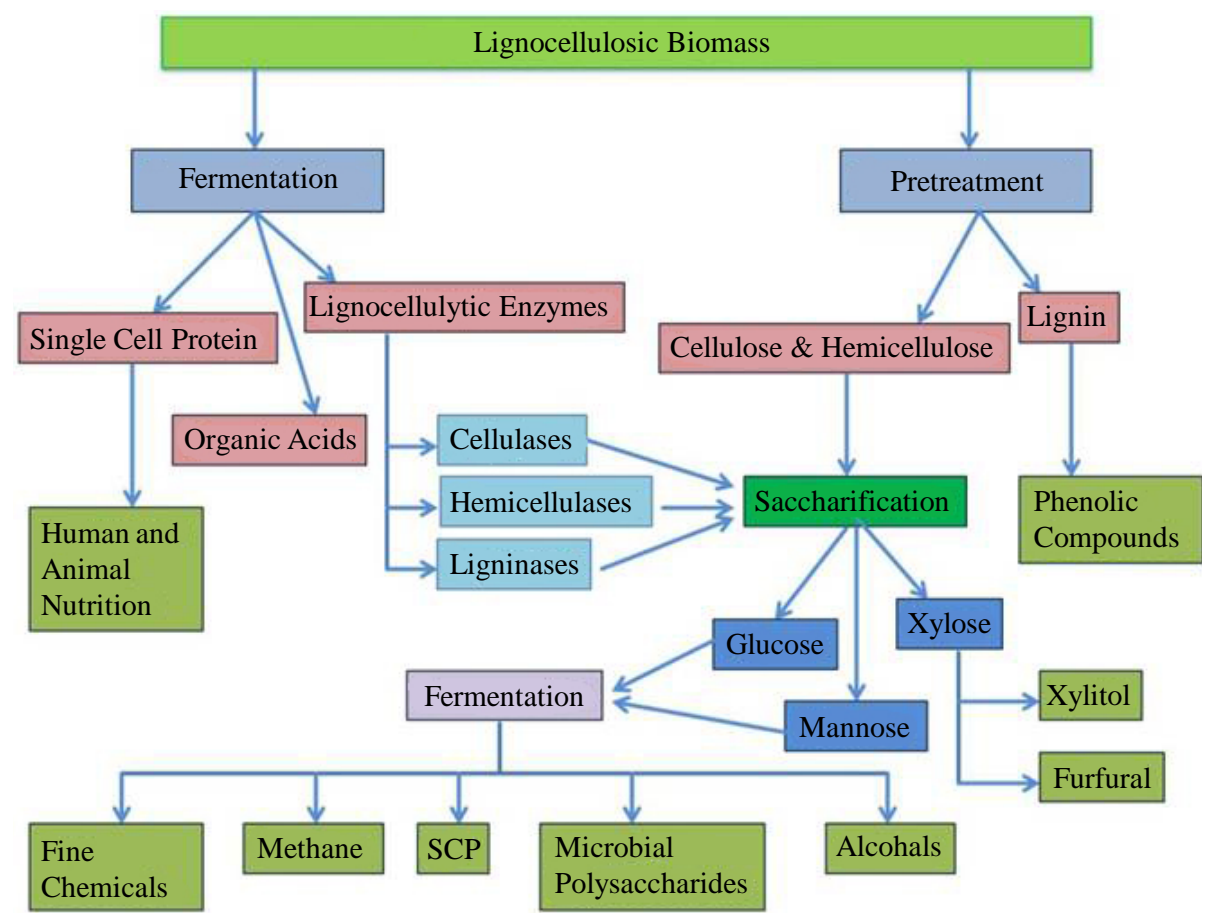

Figure 1. Bioconversion of lignocellulosic biomass into value added products. 


\section{Industrial Enzymes}

From the last several years, the demand of industrially important enzymes such as cellulases, xylanases, lignases, pectinases, and proteases increased due to their wide applications in various industries. These enzymes are produced from by different microorganisms by solid-state fermentation or submerged fermentation of lignocellulosic biomass cost effectively. Different lignocellulosic biomasses such as wheat bran, wheat straw, rice bran, rice straw, sugarcane bagasse, corn cob, corn stover and other agro-industrial residues have been utilized for the production of industrial enzymes (Table 2) [44]-[60] [62]-[92]. Lignocellulolytic enzymes are most important among them because they are also used for hydrolysis of lignocellulosic biomass in to other enzyme-based products [39]. Carbohydrates (cellulose and hemicelluloses) are hydrolyzed by cellulases and xylanases to monomer sugars such as glucose, xylose, mannose, arabinose and galactose. These monomer sugars are utilized as carbon sources for the production of different industrial products such as ethanol, xylitol, biobutanol, bio-hydrogen, microbial polysaccharides, organic acids, and single cell proteins etc [93] [94].

Table 2. Bioconversion of different lignocellulosic biomass into industrial products.

Bioconversion of different lignocellulosic biomass into industrial products
Wheat bran
Total cellulase (8.03 FPU/gds), endoglucanase (27.49 IU/gds), xylanase (2,165.44 IU/gds) by Trichoderma harzianum
PPDDN10 using wheat bran under SSF

Xylanase (727.78 IU/ml), endoglucanase (0.92 IU/ml), laccase (0.64 IU/ml) produced by Coprinellus disseminates SH-1 using wheat bran under SSF

Xylanase (698.75 IU/ml), cellulase (1.01 IU/ml) and laccase (25.6 $\pm 3.2 \mathrm{IU} / \mathrm{ml})$ by Coprinus cinereus AT-1 MTCC 9695 using wheat bran as substrate under SSF

Maximum laccase activity (416.4 U/ml) obtained by submerged fermentation of wheat bran by Cerrena unicolor C-139

Amylase (327 IU/ml) produced by Aspergillus fumigatus NTCC1222 using wheat bran as substrate

Lipase activity (9.14 IU/g of dry substrate) obtained by Aspergillus niger under SSF using wheat bran as substrate

Lactic acid yield of $0.73 \mathrm{~g} / \mathrm{g}$ substrate achieved by fermentation by Lactobacillus pentosus using wheat bran as substrate

Fumaric acid 20.2 g/l was achieved by fermentation by Rhizopus oryzae using wheat bran hydrolysate as substrate

The maximum hydrogen yield of $128.2 \mathrm{ml} / \mathrm{g}$ total volatile solid from pre-treated wheat bran by mixed anaerobic cultures

\section{Wheat straw}

Yields of endoglucanase, cellobiohydrolase, $\beta$-glucosidase, xylanase and $\beta$-xylosidase were found 1709, 4, 79, 5.5, 4490 and $45 \mathrm{U}$ per $\mathrm{g}$ of dry wheat straw by Thermoascus aurantiacus under SSF

Pretreated wheat straw hydrolyzed and fermented into acetone-butanol-ethanol $\left(0.31 \mathrm{~g} \cdot \mathrm{L}^{-1} \cdot \mathrm{h}^{-1}\right)$ by Clostridium beijerinckii P260.

Specific methane and biogas production yield of $165.9 \mathrm{~L} / \mathrm{kg}$ VS and $353.2 \mathrm{~L} / \mathrm{kg}$ VS respectively was obtained by the $\mathrm{NaOH}$ pretreated wheat straw

\section{Rice straw}

Maximum endoglucanase, Fpase, $\beta$-glucosidase, cellobiohydrolase and xylanase produced 240.2, 9.73, 470, 15 and 2800 (units/g of substrate) of activities by Aspergillus fumigatus fresenius by using rice straw as substrate

Ethanol yield $(0.48 \mathrm{~g} / \mathrm{g})$ and xylitol concentration of $0.89 \mathrm{~g} / \mathrm{l}$ were obtained from rice straw hydrolyzate Candida tropicalis ATCC13803

Alkali-pretreated rice straw decomposed up to 68.21\% by cellulase from Trichoderma reesei ZM4-F3

Enzymatic hydrolysis of organosolv pretreated rice straw resulted in glucose yield of $46.2 \%$, which was fermented to 80.3 g butanol, 21.1 g acetone, and 22.5 g ethanol by Clostridium acetobutylicum.

Maximum methane yield of $225.3 \mathrm{~mL} / \mathrm{g}$ VS achieved by anaerobic digestion of $\mathrm{Ca}(\mathrm{OH})_{2}$ treated rice straw

Methane yields of $(0.33-0.35) \mathrm{m}^{3} / \mathrm{kg}$-VS loaded observed by anaerobic digestion of rice straw

\section{Rice bran}

Highest FPase, avicelase and CMCase activities found 11.68, 99.75 and $94.21 \mathrm{U} / \mathrm{g}$ dry weight of substrate respectively byTrichoderma reesei QM9414 under SSF using rice bran as substrate 


\section{Continued}

Lactobacillus brevis producedmaximum lactic acid concentration $(39.1 \mathrm{~g} / \mathrm{l})$ by the fermentation of acid hydrolysate of corncob with $56.9 \mathrm{~g} / \mathrm{l}$ total sugars in $48 \mathrm{~h}$.

\section{Rice husk}

Through co-culture of Saccharomyces cerevisiae and Scheffersomyces stipitis, maximum $20.8 \mathrm{~g} / \mathrm{l}$ of ethanol produced from rice husk hydrolyzate containing $70 \mathrm{~g} / \mathrm{l}$ of reducing sugars

Acid hydrolysate of rice husk fermented to xylitol by Candida guilliermondii and Candida tropicalis and highest yield of xylitol was achieved upto $64.0 \%(\mathrm{w} / \mathrm{w})$.

Maximam hydrogen yield $\left(0.74 \mathrm{mmol} \mathrm{H}_{2} / \mathrm{g}\right.$-VS added straw) was obtained from anaerobic co-digestion of rice straw and sewage sludge

\section{Corncob}

Cellulase activity observed (213.4 IU/g cellulose) in submerged fermentation by Trichoderma reeseiZU-02 using corn cob as substrate

Fermentation of corncob hemicellulose powder containing $4.5 \mathrm{~g} / \mathrm{l}$ as xylan content produced $3.01 \mathrm{~g} / \mathrm{l}$ of xylitol by Candida tropicalis.

Maximum $119 \mathrm{ml} \mathrm{H}_{2} / \mathrm{g}$ corn cob produced from enzymatic hydrolysate of corn cob by the fermentation through Clostridium hydrogeniproducens HR-1

\section{Maize (corn) stover}

Highest yields of endoglucanase, cellobiohydrolase, $\beta$-glucosidase, xylanase and $\beta$-xylosidase were observed 304, 4.1, $0.140,1840$ and $0.041 \mathrm{U} / \mathrm{g}$ of corn stover by Fusarium oxysporum under SSF conditions

Hydrolysis of corn stover released $97 \%$ of the sugars and fermented completely by Clostridium beijerinckii in $60 \mathrm{~h}$ resulting in a productivity of acetone-butanol $\left(0.34 \mathrm{~g} \cdot \mathrm{L}^{-1} \cdot \mathrm{h}^{-1}\right)$.

Total soluble sugar (562.1 mg/g-TVS) obtained by enzymatic hydrolysis of acid pretreatment of cornstalk which produced maximum hydrogen yield (209.8 ml/g-TVS) achieved by anaerobic mixed microflora

Highest biogas yield of $372.4 \mathrm{~L} / \mathrm{kg}$ VS was obtained by anaerobic digestion of $5 \%$ $\mathrm{NaOH}$-pretreated corn stover

Highest methane yield of 216.7 and $206.6 \mathrm{~mL} \mathrm{CH}_{4} / \mathrm{g}$ VS obtained from $3 \% \mathrm{H}_{2} \mathrm{O}_{2}$ and $8 \% \mathrm{Ca}(\mathrm{OH})_{2}$ treated corn straw by anaerobic digestion

\section{Sugarcane bagasse}

FPase (24.15 U/gds) achieved in optimized conditions by Trichoderma reeseiRUT C30 using sugarcane bagasse as substrate under SSF

Pretreated sugarcane bagasse was hydrolyzed by crude enzyme from Penicilliumchrysogenum BCC4504 and Aspergillus flavus BCC7179and bagasse hydrolysate was converted into ethanol ( $0.29 \mathrm{~g}$ ethanol/g available fermentable sugars).

Sugarcane bagasse hydrolysate converted into xylitol (yield 61.5\%) byCandida guilliermondii FTI 20037.

Hydrogen yield of $1.86 \mathrm{~mol} \mathrm{H}_{2} / \mathrm{mol}$ total sugar achieved by the fermentation of acid hydrolysate of sugarcane bagasse

\section{Paper mill sludge}

Yield of cellulase (307 FPU/g glucan of de-ashed paper mill sludge) was achieved by Trichoderma reesei Rut C-30 and simultaneous saccharification and fermentation was performed to produce $24.4 \mathrm{~g} / \mathrm{L}$ of ethanol

Fermentation by Pichia stipitis produced $18.6 \mathrm{~g} / \mathrm{L}$ of ethanol from $178.6 \mathrm{~g} / \mathrm{L}$ of dried recycled paper sludge with conversion yield of $51 \%$ of the available carbohydrates.

In Semi-continuous simultaneous saccharification and co-fermentation of paper sludge containing $100 \mathrm{~g} / \mathrm{L}$ cellulose equivalent, with 4 days residence time and 15FPU/g of cellulase loading, two strains of Bacillus coagulans produced 80.6 and $81.7 \mathrm{~g} / \mathrm{L}$ of lactic acid respectively.

Highest methane yield $\left(0.32 \mathrm{~m}^{3} \mathrm{CH}_{4} / \mathrm{kg}\right.$ VS) was obtained from pretreated paper mill sludge

\section{Sunflower}

Pretreated sunflower hulls hydrolyzed by cellulase from Trichoderma reesei Rut C 30 up to 59.8\% saccharification yield and ethanol produced $(0.454 \mathrm{~g} / \mathrm{g})$ by Saccharomyces cerevisiae var. ellipsoideus using the concentrated hydrolyzate.

Highest methane production $\left(259 \mathrm{~mL} \mathrm{CH}_{4} / \mathrm{g}\right.$ VS) achieved after pretreatment of sunflower stalk at $55^{\circ} \mathrm{C}$ with $4 \% \mathrm{NaOH}$ by anaerobic digestion

\section{Water-hyacinth (Eichhornia crassipes)}

Maximum ethanol yield ( $0.35 \mathrm{~g} / \mathrm{g}$ sugars) obtained from water-hyacinth hemicellulose acid hydrolysate by Pichia stipitis NRRL Y-7124.

Maximum saccharification yield (71\%) obtained by using cellulases and xylanases from Trichodermareesei RUT C30 and Aspergillus niger MTCC 7956 and the hydrolyzate was converted into ethanol (4.4 g/L) by Saccharomyces cerevisiae. 


\section{Bio-Energy}

The world energy demand continues to increase, according to U.S. Energy Information Administration data; consumption of energy in the world will rise by $56 \%$ between 2010 and 2040 [95]. This dramatic increase of world energy consumption (154 to 240 quadrillion Watt-hour) is very difficult to achieve from diminishing fossil fuel reserves. Therefore, efforts have been directed towards promising alternatives for fossil fuels and the conversion of lignocellulosic biomass to biofuels is the sustainable choice for that [96]. Lignocellulosic biomass is a natural renewable resource for second generation bioenergy products. Bioethanol, biobutanol, biomethane and biohydrogen are the bioenergy products that are produced from lignocellulosic biomass.

\subsection{Bioethanol}

Ethanol produced from lignocellulosic biomass provides unique environmental, economic, and strategic benefits [97]. Bioethanol is an important replacement of fossil fuel, production of bioethanol is increasing rapidly. Lignocellulosic biomass such as agricultural, industrial and forest residuals are recognized widely as excellent low cost and abundantly available feedstock for bioethanol production [76] [97]. Ethanol presently has the largest market due to its use as a chemical feedstock or as a fuel additive or primary fuel [1] [98]. Conversion of lignocellulosic biomass into bioethanol consists of three steps. In the first step, pretreatment is carried out to make cellulose and hemicellulose available for hydrolysis by breaking the compact lignocellulosic structure [76]. Several physical, chemical and biological pretreatment methods have been studied for improving the hydrolysis of lignocellulosic biomass [99]. The second step aims at hydrolysing the holocellulose into fermentable sugars by the action of lignocellulolytic enzymes. In the third step, fermentable sugars during enzymatic hydrolysates are converted in to ethanol after proper detoxification process [100]. Fermentation of fermentable sugars is carried out with different microorganisms such as Saccharomyces cerevisiae, Saccharomyces cerevisaiae var. ellipoideus, Scheffersomyces stipitis, Escheria coli, Zymomonas mobilis, Pachysolen tannophilus, Candida brassicae, Candida glabrata, Candida shehate, Candida tropicalis, Pichia stipitis, Kluyveromyces marxianus, Mucor indicus etc. [44] [45] [76] [92] [97] [101]-[106]. Various lignocellulosic biomass such as sugarcane bagasse, water hyacinth, rice straw, rice husk, wheat straw, reed, bermuda grass, and rapeseed stover, corn cob, sunflower hulls, sunflower stalks, lemon peel waste, empty fruit bunches of oil palm, sweet sorghum have been tested for ethanol production [1] [14] [73] [76] [90]-[92] [106]-[110].

\subsection{Biobutanol}

Biobutanol is considered as future biofuel which have potential to replace gasoline. 1-Butanol as fuel is advantageous over ethanol in terms of energy density, engine compatibility and safety [111] [112]. 1-Butanol is also an important precursor for paints, polymers, and plastics. [113] Different members of genus Clostridium such as C. acetobutylicum, C. beijerinckii, C. saccharoperbutylacetonicum, C. saccharoperbutylicum, C. sporogenes, C. perfrigens, C. pasteurianum, C. carboxidivorus, C. tetanomorphum, C. aurantibutyricum, C. cadaveris, C. butylicum etc. are used for the production of biobutanol through acetone-butanol-ethanol (ABE) fermentation [47] [48] [70] [111] [113]-[115]. For the production of butanol various substrates such as molasses, whey permeate, corn, cassava, and potato etc. have been used traditionally. These biomasses are costly and compete with food supply therefore, lignocellulosic biomass is the suitable source for cost effective and sustainable production of biobutanol [111] [114]. A number of lignocellulosic substrates like rice bran, corn stover, wheat bran, wheat straw, palm kernel cake, rice straw and wood chips have been utilized for the production of biobutanol in various studies [46]-[48] [70] [111] [113] [114] [116].

\subsection{Biomethane}

Biomethane has potential to yield more energy than any other current of biofuels like bioethanol and biodiesel. Anaerobic digestion or biomethanation is the microbial process which converts organic materials into biogas in the absence of oxygen. Biogas mainly consists of methane and carbon dioxide, used for the production of electricity and heat for local needs [117] [118]. Biogas can also be used as vehicle fuel where biogas is cleaned and upgraded to biomethane which is combusted in an internal combustion engine [119] [120]. El-Mashad [121] reported in a study that estimated gross energy $\left(6774 \mathrm{MJ}_{\text {tonne }}{ }^{-1}\right)$ in the form of biomethane through anaerobic digestion of untreated switchgrass was significantly higher than gross energy (3904 MJ tonne ${ }^{-1}$ ) which was 
estimated in terms of bioethanol, produced from alkali-treated and saccharified switchgrass. Cattle manures have low biogas yield which can be improved by co-digestion of manure, crop residues and organic wastes. Various studies showed the production of biomethane from wide range of lignocellulosic biomass such as rice straw, sorghum forage, pulp and paper sludge, softwood spruce, birch, corn stover, wheat straw, sunflower stalk and fallen leaves [1] [51]-[53] [71] [83] [91] [117] [122]-[126].

\subsection{Bio-Hydrogen}

Bio-hydrogen is also regarded as a viable energy option in future which is clean and renewable energy carrier as its combustion produces the water as the sole end product. Hydrogen has higher energy content as compared to hydrocarbon fuels and fossil fuels which are the main source for hydrogen production worldwide [61] [127]. Hydrogen can be produced from carbohydrate containing biomass by bacterial hydrogen fermentation to satisfy hydrogen demand in future [61]. Different mesophilic, thermophilic and extreme thermophilic microorganisms such as Clostridium tyrobutyricum, C. butyricum, C. beijerinckii, Enterobactter aerogenes, E. cloacae, Thermoanaerobacterium thermosaccharolyticum, Caldicellulosiruptor saccharolyticus, Thermotoga neapolitana, Thermotoga elfii, Ethanoligenens etc. are utilized for the production of hydrogen [61] [127]-[133]. Pure cultures and mixed cultures both are used for conversion of lignocellulosic biomass into hydrogen. Anaerobic digested sludge or compost which contains various microorganisms are the natural source for the hydrolysis of cellulose [128]. Song et al. [129] enumerated natural microbial consortium from compost for hydrogen fermentation and reported Clostridium sp, Enterobacter sp, Bacteroides sp, Veillonella sp, and Streptococcus sp. as essential members of natural microbial consortium. Different lignocellulosic biomasses including hemp, newspaper, barley straw, rice straw, corn stalk, corn cob, wheat bran, wheat straw, compost, sugarcane bagasse, and sweet sorghum bagasse, have been utilized for the production of hydrogen (Table 2) [49] [50] [68] [80] [82] [127]-[129] [134]-[136].

\section{Organic Acids}

Organic acids are the natural products or at least natural intermediate of major metabolic pathways of microorganisms. Organic acids are extremely useful products due to their functional group which make them suitable substrate for the synthesis of other important chemicals. [137] Organic acids can be produced either by using sugars such as glucose, xylose and sucrose or by using hydrolysate from lignocellulosic biomass. Different organic acids such as citric acid, acetic acid, succinic acid, gluconic acid, oxalic acid, lactic acid, malic acid, butyric acid, fumaric, etc. are produced by microbial fermentation of by using the lignocellulose as substrate [137]-[140].

\subsection{Citric Acid}

Citric acid is the second largest fermentation product after ethanol worldwide with 1.7 million tons of annual production. Citric acid is a commodity chemical which has broad range of versatile applications in biomedicine, nanotechnology, bioremediation of heavy metals [138] [141]. Citric acid is produced dominantly by Aspergillus niger under submerged and solid-state fermentations and other producers of citric acid are Absidia sp, Acremonium sp, Botrytis sp, A. flavus, A. awamori, A. nidulans, A. phoenicus, A wenti, Penicillium citrinum, P. janthinellu, P. Luteum, P. restrictum, Tricoderma viride, and Talaromyces sp. [56] [138] [141]-[144]. Cirtic acid is produced using different lignocellulosic biomass such as sugarcane bagasse [56] [57], oil palm empty fruit bunches [145], apple pomace [46] [138], cassava bagasse [139] [142], cotton waste [147], corn cobs [148], corn husk [149], pineapple waste [150], grape and pomace [146] etc.

\subsection{Succinic Acid}

Succinic acid is a C4 dicarboxylic acid which is a very useful chemical in food, agricultural and pharmaceutical industries. Succinic acid is a platform chemical which is used as feedstock for the production various high value derivatives such as adipic acid, 1, 4 butanediol, methyl ethyl ketone, 1, 3-butadiene, ethylene diamine disuccinate [151]-[153]. Currently, succinic acid is synthesized from petroleum based chemical processes commercially. Due to depleting of oil reserves, rising prices and environmental pollution, succinic acid production through fermentation using low cost substrates such as lignocellulosic biomass has attracted more and more attention in 
recent years [151] [153] [154]. To date, different renewable lignocellulosic biomass used for succinic acid production are wood hydrolysate [155], corn stover [153] [156], corn stalk hydrolysate [151] [154], sugarcane bagasse hydrolysate [152], pinewood [156], and Cannabis sativaL [157]. Microorganisms that naturally produce the succinic acid are Actinobacillus succinogenes [153] [156] [157], Anaerobiospirillum succiniciproducens [156], Klebsislla pneumonia [158], and Mannheimia succiniciproducens [155] etc. Along with these microbial strains, genetically engineered E. Coli. [151] [152] [154] and Saccharomyces cerevisiae [159] have also been used successfully for the production of succinic acid [156].

\subsection{Lactic Acid}

Lactic acid is one of the most versatile organic acids which have broad range of applications in food, textile, and pharmaceutical cosmetic and chemical industries [160]. World demand for lactic acid have been estimated 600,000 tons by 2020 and is expected to keep increasing in due to its use in production of poly-lactic acid and lactate solvents [161]. Poly-lactic acid is biodegradable and biocompatible polymer which can replace plastics derived from petrochemicals [162] [163]. Lactic acid is synthesized chemically or produced by microbial fermentation. Currently, almost all lactic acids produced globally by microbial fermentation due to several advantages including production of optically pure L-or D-lactic acid, low production temperature, and decreased energy consumption. However, traditional substrates including starch and refined sugars constitutes for the major proportion of production cost. Therefore, lignocellulosic biomass is cost effective and non-food material for the production of lactic [162]-[164]. Lignocellulosic biomass substrates such as rice bran [165], corn stover [166], corn cob [166], paper sludge [88], sugarcane bagasse [167] [168], wheat bran [169] [170], and office waste paper [171] etc. are utilized for the production of lactic acid. Lactic acid is produced by fermentation using different microorganisms such as Bacillus coagulans [88] [162], Lactobacillus brevis [166], Lactobacillus coryniformis [172], Lactbacillus casei [167], Lactobacillus delbrueckii [170], Lactobacillus rhamnosus [165] [169], Lactococcuslactis [173], Lactbacillus pentosus [173], Streptococcus thermophilus [167] [173], and Rhizopus oryzae [171].

\subsection{Acetic Acid}

Acetic acid, formic acid and levulinic acid are formed by acid-catalyzed conversion of lignocellulosic biomass. Acetic acid is formed by hydrolysis of acetyl group of hemicelluloses. Formic acid is produced by degradation of furfural and 5-hydroxymethylfurfural (HMF) while levulinic acid is degradation product of HMF. Furfural and HMF are formed by pentose (e.g. xylose and arabinose) and hexose (e.g. glucose, mannose and galactose) sugars respectively [54] [55]. Levulinic acid is a versatile platform chemical that can be used for the synthesis of different chemicals such as $\gamma$-valerolactone, succinic acid, resin, polymers, herbicides, pharmaceuticals and flavouring agents [174] [175]. Acetic acid and formic acid are effective in the fractionation of lignocellulosic biomass to produce the cellulosic pulp and other products. Acetic acid and formic acid have been used for the fractionation of lignocellulosic biomass from different sources such as dhaincha (Sesbania aculeata), kash (Saccharum spontaneum), banana stem (Musa cavendish) and jute fibre [176]-[178].

\section{Microbial Polysaccharides}

Exopolysaccaharide are produced by wide variety of microorganisms which are very useful in different industries due to their novel and unique physical properties [179]. Microbial polysaccharides have diverse applications in different industrial sectors such as food, petroleum, and pharmaceutical industries. Because of their higher cost of production, microbial polysaccharides comprise of a small fraction of current polymer market. Low cost fermentation substrates are required to get down the cost of microbial polysaccharides and lignocellulosic biomass are the potential sources for their production [180]. Different microbial bioactive polysaccharides such as schizophyllan, pullulan, xanthan, dextran, curdlan etc. are produced by microorganisms using fermentable sugars as the substrate. Hydrolysates from different lingocellulosic biomass are the potential source of fermentable sugars which can be utilized for the production of microbial polysaccharides cost effectively. Schizophyllan is a polysaccharide produced by the strains of a white rot fungus, Schizophyllum commune. Schizophyllan consists of $\beta-1,3$ linked glucose backbone with single $\beta-1,6$ linked glucose side chains at every other residues. Shu and Hsu [181] used rice hull hydrolysate for the production of schizophyllan and found $81.3 \mathrm{mg} / \mathrm{l}$ of schizophyllan by Schizophyllum commune. Pullulan ispolysaccharide consisting of maltotriose units joined by 
$\alpha-(1 \rightarrow 6)$ linkage, produced by a fungus Aureobasidium pullulans [182]-[184]. Wang et al. [182] studied the production of pullulan and obtained $22.2 \mathrm{~g} / \mathrm{l}$ of pullulan by using rice hull hydrolysate as the substrate from the mutant of Aureobasidium pullulans. Sugumaran et al. [184] studied the production of pullulan by using rice bran, wheat bran, coconut kernel and palm kernel as the substrate and observed maximum pullulan production by palm kernel. Another very important microbial polysaccharide is xanthan which is hetero-polysaccharide of pentasaccharide repeating units, containing D-glucose, D-mannose, D-glucuronic acid (at the ratio-2:2:1). Xanthan is produced by aerobic fermentation of bacteria Xanthomonas campestris on glucose or sucrose based media [185] [186]. Moreno et al. [186] tested hydrolysate of different lignocellulose biomass including Lycopersicum esculetum, Cucumis melo, Citrullus lanatus, Cucumis sativus for xanthan production and reported maximum xanthan production using Cucumis melo hydrolysate.

\section{Single-Cell Proteins}

Continuous growth of population in developing countries needs an increase protein enriched animal feed and human food supply. Single-cell proteins are such alternatives which can solve the global food problems [187]. Term single-cell protein refers the dried microbial cell or total protein extracted from pure microbial cultures including algae, bacteria, fungi and yeasts. Single-cell proteins are used as human food supplement or animal feed [187]-[189]. Lignocellulosic wastes are low cost substrates for the production of single-cell proteins. Different lignocellulosic wastes such as apple waste, banana peel, and cucumber peel, Eichornia waste, mango waste, papaya waste, pineapple waste, orange peel, rice bran, watermelon skin, and wheat bran etc have been used for the production for single-cell protein successfully [187]-[191].

\section{Xylitol}

Xylitol is a five carbon high value sugar alcohol, derived from xylose which is naturally found in some fruits and vegetables. Xylitol is used as an anticarciogenic agent in toothpastes, as coating on vitamin tablets, in chewing gum, in soft drinks, and in bakery products. Xylitol is equivalent to sucrose in sweetness and metabolized by an insulin independent pathway therefore, it is used as sweetener agent for diabetic persons [79] [192] [193]. Currently, xylitol is produced by conventional method in which chemical hydrogenation of pure xylose takes place in the presence of nickel catalyst at high temperature and pressure. The yield of xylitol is 50\% - 60\% of xylan fraction and the chemical process is cost and energy intensive. Microbial production of xylitol is the highly attractive and alternative method which is able to produce high quality product cost effectively because it can be achieved without high pressure, temperature or xylose purification [79] [193]-[195]. Microorganisms like bacteria, yeasts, and filamentous fungi are able to metabolize xylose for the production of xylitol but yeasts are considered the most efficient producers of xylitol. Among wild type of xylitol producing yeasts, various species of Candida are capable for the production of xylitol [79] [195].

\section{Conclusion}

In this review, chemical and physical properties of lignocellulosic biomass and their components viz. cellulose, hemicelluloses, and lignin as well as bioconversion of lignocellulosic biomass in to industrial products have been discussed. The bio-conversion of lignocellulosic biomass by industrial enzymes is a potential sustainable approach to develop value-added bio-products. A large fraction of these lignocellulosic materials is often disposed of by burning, which is not restricted to developing countries alone. However, the huge amount of residual plant biomass considered as "waste" can potentially be converted into different value-added products such as bio-ethanol, bio-methane, organic acids, microbial polysaccharides, single cell protein, lignocellulolytic enzymes, and other value added products. Biotechnological conversion of lignocellulosic biomass in various industrial products is cost effective and environmentally sustainable route.

\section{Conflict of Interests}

The authors declare that there is no conflict of interests regarding the publication of this paper.

\section{References}

[1] Kumar, R., Singh, S. and Singh, O. (2008) Bioconversion of Lignocellulosic Biomass: Biochemical and Molecular 
Perspectives. Journal of Industrial Microbiology \& Biotechnology, 35, 377-391. http://dx.doi.org/10.1007/s10295-008-0327-8

[2] Demain, A.L., Newcomb, M. and Wu, J.H.D. (2009) Cellulase, Clostridia, and Ethanol. Microbiology and Molecular Biology Reviews, 69, 124-154. http://dx.doi.org/10.1128/MMBR.69.1.124-154.2005

[3] Sanchez, C. (2009) Lignocellulosic Residues: Biodegradation and Bioconversion by Fungi. Biotechnology Advances, 27, 185-194. http://dx.doi.org/10.1016/j.biotechadv.2008.11.001

[4] Perez, J., Munoz-Dorado, J., de la Rubia, T. and Martinez, J. (2002) Biodegradation and Biological Treatments of Cellulose, Hemicellulose and Lignin: An Overview. International Microbiology, 5, 53-63. http://dx.doi.org/10.1007/s10123-002-0062-3

[5] Howard, R.L., Abotis, E., van Rensburg, E.L. and Howard, S. (2003) Lignocellulose Biotechnology: Issues of Bioconversion and Enzyme Production. African Journal of Biotechnology, 2, 602-619. http://dx.doi.org/10.5897/AJB2003.000-1115

[6] Malherbe, S. and Cloete, T.E. (2002) Lignocellulose Biodegradation: Fundamentals and Applications. Reviews in Environmental Science and Biotechnology, 1, 105-114. http://dx.doi.org/10.1023/A:1020858910646

[7] Levine, J.S. (1996) Biomass Burning and Global Change. In: Levine, J.S., Ed., Remote Sensing and Inventory Development and Biomass burning in Africa, The MIT Press, Cambridge, 35.

[8] Nanda, S., Mohammad, J., Reddy, S., Kozinski, J. and Dalai, A. (2014) Pathways of Lignocellulosic Biomass Conversion to Renewable Fuels. Biomass Conversion and Biorefinery, 4, 157-191. http://dx.doi.org/10.1007/s13399-013-0097-z

[9] Horn, S., Vaaje-Kolstad, G., Westereng, B. and Eijsink, V.G.H. (2012) Novel Enzymes for the Degradation of Cellulose. Biotechnology for Biofuels, 5, 45. http://dx.doi.org/10.1186/1754-6834-5-45

[10] Nanda, S., Mohanty, P., Pant, K., Naik, S., Kozinski, J. and Dalai, A. (2012) Characterization of North American Lignocellulosic Biomass and Biochars in Terms of Their Candidacy for Alternate Renewable Fuels. Bioenergy Research, 6, 663-677. http://dx.doi.org/10.1007/s12155-012-9281-4

[11] Rosa Estela, Q.-C.E. and Luis, F.-M.J. (2013) Hydrolysis of Biomass Mediated by Cellulases for the Production of Sugars. In: Chandel, A.K. and da Silva, S.S., Eds., Sustainable Degradation of Lignocellulosic Biomass-Techniques, Applications and Commercialization, InTech, Rijeka, Croatia, 119-155. http://dx.doi.org/10.5772/53719

[12] Bridgeman, T.G., Jones, J.M. Shield, I. and Williams, P.T. (2008) Torrefaction of Reed Canary Grass, Wheat Straw and Willow to Enhance Solid Fuel Qualities and Combustion Properties. Fuel, 87, 844-856. http://dx.doi.org/10.1016/j.fuel.2007.05.041

[13] Okeke, B.C. and Obi, S.K.C. (1994) Lignocellulose and Sugar Compositions of Some Agro-Waste Materials. Bioresource Technology, 47, 283-284. http://dx.doi.org/10.1016/0960-8524(94)90192-9

[14] Li, H., Kim, N.J., Jiang, M., Kang, J.W. and Chang, H.N. (2009) Simultaneous Saccharification and Fermentation of Lignocellulosic Residues Pretreated with Phosphoric Acid-Acetone for Bioethanol Production. Bioresource Technology, 100, 3245-3251. http://dx.doi.org/10.1016/j.biortech.2009.01.021

[15] Naik, S., Goud, V.V., Rout, P.K., Jacobson, K. and Dalai, A.K. (2010) Characterization of Canadian Biomass for Alternative Renewable Biofuel. Renewable Energy, 35, 1624-1631. http://dx.doi.org/10.1016/j.renene.2009.08.033

[16] Rowell, R.M. (1992) Opportunities for Lignocellulosic Materials and Composites. In: Rowell, R.M., Schultz, T.P. and Narayan, R., Eds., Emerging Technologies for Materials and Chemicals from Biomass, American Chemical Society, Washington DC, 12-27. http://dx.doi.org/10.1021/bk-1992-0476.ch002

[17] Ilyas, U., Ahmed, S., Majeed, A. and Nadeem, M. (2012) Exploration of Indigenous Agrowastes for Cellulase Production by Aspergillus niger. African Journal of Biotechnology, 11, 9276-9279.

[18] Prasad, S., Singh, A. and Joshi, H.C. (2007) Ethanol as an Alternative Fuel from Agricultural, Industrial and Urban Residues. Resources, Conservation and Recycling, 50, 1-39. http://dx.doi.org/10.1016/j.resconrec.2006.05.007

[19] Raveendran, K., Ganesh, A. and Khilar, K.C. (1995) Influence of Mineral Matter on Biomass Pyrolysis Characteristics. Fuel, 74, 1812-1822. http://dx.doi.org/10.1016/0016-2361(95)80013-8

[20] Kim, T.H., Kim, J.S., Sunwoo, C. and Lee, Y.Y. (2003) Pretreatment of Corn Stover by Aqueous Ammonia. Bioresource Technology, 90, 39-47. http://dx.doi.org/10.1016/S0960-8524(03)00097-X

[21] Merino, S. and Cherry, J. (2007) Progress and Challenges in Enzyme Development for Biomass Utilization. In: Olsson, L., Ed., Biofuels, Springer Berlin Heidelberg, 95-120. http://dx.doi.org/10.1007/10_2007_066

[22] Ballesteros, M., Oliva, J.M., Negro, M.J., Manzanares, P. and Ballesteros, I. (2004) Ethanol from Lignocellulosic Materials by a Simultaneous Saccharification and Fermentation Process (SFS) with Kluyveromyces marxianus CECT 10875. Process Biochemistry, 39, 1843-1848. http://dx.doi.org/10.1016/j.procbio.2003.09.011 
[23] Tang, J., Chen, K., Huang, F., Xu, J. and Li, J. (2013) Characterization of the Pretreatment Liquor of Biomass from the Perennial Grass, Eulaliopsis binata, for the Production of Dissolving Pulp. Bioresource Technology, 129, 548-552. http://dx.doi.org/10.1016/j.biortech.2012.11.096

[24] Lee, J. (1997) Biological Conversion of Lignocellulosic Biomass to Ethanol. Journal of Biotechnology, 56, 1-24. http://dx.doi.org/10.1016/S0168-1656(97)00073-4

[25] Ferreira-Leitao, V., Perrone, C.C., Rodrigues, J., Franke, A.P.M., Macrelli, S. and Zacchi, G. (2010) An Approach to the Utilisation of $\mathrm{CO}_{2}$ as Impregnating Agent in Steam Pretreatment of Sugar Cane Bagasse and Leaves for Ethanol Production. Biotechnology for Biofuels, 3, 7. http://dx.doi.org/10.1186/1754-6834-3-7

[26] Mansoer, Z., Reeves, D.W. and Wood, C.W. (1997) Suitability of Sunn Hemp as an Alternative Late-Summer Legume Cover Crop. Soil Science Society of America Journal, 61, 246-253. http://dx.doi.org/10.2136/sssaj1997.03615995006100010034x

[27] Kabel, M.A., van der Maarel, M.J.E.C., Klip, G., Voragen, A.G.J. and Schols, H.A. (2006) Standard Assays Do Not Predict the Efficiency of Commercial Cellulase Preparations towards Plant Materials. Biotechnology and Bioengineering, 93, 56-63. http://dx.doi.org/10.1002/bit.20685

[28] Hendriks, A.T.W.M. and Zeeman, G. (2009) Pretreatments to Enhance the Digestibility of Lignocellulosic Biomass. Bioresource Technology, 100, 10-18. http://dx.doi.org/10.1016/j.biortech.2008.05.027

[29] Singhania, R.R., Sukumaran, R.K., Patel, A.K., Larroche, C. and Pandey, A. (2010) Advancement and Comparative Profiles in the Production Technologies Using Solid-State and Submerged Fermentation for Microbial Cellulases. Enzyme and Microbial Technology, 46, 541-549. http://dx.doi.org/10.1016/j.enzmictec.2010.03.010

[30] Agbor, V.B., Cicek, N., Sparling, R., Berlin, A. and Levin, D.B. (2011) Biomass Pretreatment: Fundamentals toward Application. Biotechnology Advances, 29, 675-685. http://dx.doi.org/10.1016/j.biotechadv.2011.05.005

[31] Van Dyk, J.S. and Pletschke, B.I. (2012) A Review of Lignocellulose Bioconversion Using Enzymatic Hydrolysis and Synergistic Cooperation between Enzymes-Factors Affecting Enzymes, Conversion and Synergy. Biotechnology Advances, 30, 1458-1480. http://dx.doi.org/10.1016/j.biotechadv.2012.03.002

[32] Eriksson, K.-E.L. and Bermek, H. (2009) Lignin, Lignocellulose, Ligninase. Applied Microbiololgy Industrial, 373384.

[33] Juturu, V. and Wu, J.C. (2012) Microbial Xylanases: Engineering, Production and Industrial Applications. Biotechnology Advances, 30, 1219-1227. http://dx.doi.org/10.1016/j.biotechadv.2011.11.006

[34] Beg, Q.K., Kapoor, M., Mahajan, L. and Hoondal, G.S. (2001) Microbial Xylanases and Their Industrial Applications: A Review. Applied Microbiology and Biotechnology, 56, 326-338. http://dx.doi.org/10.1007/s002530100704

[35] Collins, T., Gerday, C. and Feller, G. (2005) Xylanases, Xylanase Families and Extremophilic Xylanases. FEMS Microbiology Reviews, 29, 3-23. http://dx.doi.org/10.1016/j.femsre.2004.06.005

[36] Prade, R.A. (1996) Xylanases: From Biology to Biotechnology. Biotechnology and Genetic Engineering Reviews, 13, 101-132. http://dx.doi.org/10.1080/02648725.1996.10647925

[37] Bastawde, K.B. (1992) Xylan Structure, Microbial Xylanases, and Their Mode of Action. World Journal of Microbiology and Biotechnology, 8, 353-368. http://dx.doi.org/10.1007/BF01198746

[38] Uffen, R.L. (1997) Xylan Degradation: A Glimpse at Microbial Diversity. Journal of Industrial Microbiology and Biotechnology, 19, 1-6. http://dx.doi.org/10.1038/sj.jim.2900417

[39] Shahzadi, T., Mehmood, S., Irshad, M., Anwar, Z., Afroz, A., Zeeshan, N., Rashid, U. and Sughra, K. (2014) Advances in Lignocellulosic Biotechnology: A Brief Review on Lignocellulosic Biomass and Cellulases. Advances in Bioscience and Biotechnology, 5, 246-251. http://dx.doi.org/10.4236/abb.2014.53031

[40] Mussatto, S.I. and Teixeira, J.A. (2010) Lignocellulose as Raw Material in Fermentation Processes. In: Mendez-Vilas, A., Ed., Current Research, Technology and Education, Topics in Applied Microbiology and Microbial Biotechnology, Formatex Research Center, Badajoz, 897-907.

[41] Zhao, X., Zhang, L. and Liu, D. (2012) Biomass Recalcitrance Part I: The Chemical Compositions and Physical Structures Affecting the Enzymatic Hydrolysis of Lignocellulose. Biofuels, Bioproducts and Biorefining, 6, 465-482. http://dx.doi.org/10.1002/bbb.1331

[42] Nascimento, M.S., Santana, A.L.B.D., Maranhão, C.A., Oliveira, L.S. and Bieber, L. (2013) Phenolic Extractives and Natural Resistance of Wood. In: Chamy, R. and Rosenkranz, F., Eds., Biodegradation-Life of Science, InTech, Rijeka, Croatia, 349-370.

[43] Coombs, J., Lynch, J.M., Levy, J.F. and Gascoigne, J.A. (1987) EEC Resources and Strategies and Discussion. Philosophical Transactions of the Royal Society of London. Series A, Mathematical and Physical Sciences, 321, 405-422. http://dx.doi.org/10.1098/rsta.1987.0019

[44] Oberoi, H.S., Vadlani, P.V., Brijwani, K., Bhargav, V.K. and Patil, R.T. (2010) Enhanced Ethanol Production via Fermentation of Rice Straw with Hydrolysate-Adapted Candida tropicalis ATCC 13803. Process Biochemistry, 45, 1299- 
1306. http://dx.doi.org/10.1016/j.procbio.2010.04.017

[45] Buaban, B., Inoue, H., Yano, S., Tanapongpipat, S., Ruanglek, V., Champreda, V., Pichyangkura, R., Rengpipat, S. and Eurwilaichitr, L. (2010) Bioethanol Production from Ball Milled Bagasse Using an On-Site Produced Fungal Enzyme Cocktail and Xylose-Fermenting Pichia stipitis. Journal of Bioscience and Bioengineering, 110, 18-25. http://dx.doi.org/10.1016/j.jbiosc.2009.12.003

[46] Amiri, H., Karimi, K. and Zilouei, H. (2014) Organosolv Pretreatment of Rice Straw for Efficient Acetone, Butanol, and Ethanol Production. Bioresource Technology, 152, 450-456. http://dx.doi.org/10.1016/j.biortech.2013.11.038

[47] Al-Shorgani, N., Kalil, M. and Yusoff, W. (2012) Biobutanol Production from Rice Bran and De-Oiled Rice Bran by Clostridium saccharoperbutylacetonicum N1-4. Bioprocess and Biosystems Engineering, 35, 817-826. http://dx.doi.org/10.1007/s00449-011-0664-2

[48] Qureshi, N., Singh, V., Liu, S., Ezeji, T.C., Saha, B.C. and Cotta, M.A. (2014) Process Integration for Simultaneous Saccharification, Fermentation, and Recovery (SSFR): Production of Butanol from Corn Stover Using Clostridium beijerinckii P260. Bioresource Technology, 154, 222-228. http://dx.doi.org/10.1016/j.biortech.2013.11.080

[49] Lai, Z., Zhu, M., Yang, X., Wang, J. and Li, S. (2014) Optimization of Key Factors Affecting Hydrogen Production from Sugarcane Bagasse by a Thermophilic Anaerobic Pure Culture. Biotechnology for Biofuels, 7, 119. http://dx.doi.org/10.1186/s13068-014-0119-5

[50] Kim, M., Yang, Y., Morikawa-Sakura, M.S., Wang, Q., Lee, M.V., Lee, D.-Y., Feng, C., Zhou, Y. and Zhang, Z. (2012) Hydrogen Production by Anaerobic Co-Digestion of Rice Straw and Sewage Sludge. International Journal of Hydrogen Energy, 37, 3142-3149. http://dx.doi.org/10.1016/j.ijhydene.2011.10.116

[51] Song, Z., Yang, G., Han, X., Feng, Y. and Ren, G. (2013) Optimization of the Alkaline Pretreatment of Rice Straw for Enhanced Methane Yield. BioMed Research International, 2013, Article ID: 968692. http://dx.doi.org/10.1155/2013/968692

[52] Lei, Z., Chen, J., Zhang, Z. and Sugiura, N. (2010) Methane Production from Rice Straw with Acclimated Anaerobic Sludge: Effect of Phosphate Supplementation. Bioresource Technology, 101, 4343-4348. http://dx.doi.org/10.1016/j.biortech.2010.01.083

[53] Monlau, F., Barakat, A., Steyer, J.P. and Carrere, H. (2012) Comparison of Seven Types of Thermo-Chemical Pretreatments on the Structural Features and Anaerobic Digestion of Sunflower Stalks. Bioresource Technology, 120, 241247. http://dx.doi.org/10.1016/j.biortech.2012.06.040

[54] Deng, W., Zhang, Q. and Wang, Y. (2014) Catalytic Transformations of Cellulose and Cellulose-Derived Carbohydrates into Organic Acids. Catalysis Today, 234, 31-41. http://dx.doi.org/10.1016/j.cattod.2013.12.041

[55] Jönsson, L.J., Alriksson, B. and Nilvebrant, N.-O. (2013) Bioconversion of Lignocellulose: Inhibitors and Detoxification. Biotechnology for Biofuels, 6, 16. http://dx.doi.org/10.1186/1754-6834-6-16

[56] Kumar, A. and Jain, V.K. (2008) Solid State Fermentation Studies of Citric Acid Production. African Journal of Biotechnology, 7, 644-650. http://www.academicjournals.org/AJB

[57] Khosravi-Darani, K. and Zoghi, A. (2008) Comparison of Pretreatment Strategies of Sugarcane Baggase: Experimental Design for Citric Acid Production. Bioresource Technology, 99, 6986-6993. http://dx.doi.org/10.1016/j.biortech.2008.01.024

[58] Wang, G., Huang, D., Li, Y., Wen, J. and Jia, X. (2015) A Metabolic-Based Approach to Improve Xylose Utilization for Fumaric Acid Production from Acid Pretreated Wheat Bran by Rhizopus oryzae. Bioresource Technology, 180, 119-127. http://dx.doi.org/10.1016/j.biortech.2014.12.091

[59] Tirpanalan, Ö., Reisinger, M., Smerilli, M., Huber, F., Neureiter, M., Kneifel, W. and Novalin, S. (2015) Wheat Bran Biorefinery-An Insight into the Process Chain for the Production of Lactic Acid. Bioresource Technology, 180, 242249. http://dx.doi.org/10.1016/j.biortech.2015.01.021

[60] Carvalho, W., Silva, S.S., Vitolo, M., Felipe, M.G. and Mancilha, I.M. (2002) Improvement in Xylitol Production from Sugarcane Bagasse Hydrolysate Achieved by the Use of a Repeated-Batch Immobilized Cell System. Zeitschrift für Naturforschung C, 57, 109-112. http://dx.doi.org/10.1515/znc-2002-1-219

[61] Urbaniec, K. and Bakker, R.R. (2015) Biomass Residues as Raw Material for Dark Hydrogen Fermentation-A Review. International Journal of Hydrogen Energy, 40, 3648-3658. http://dx.doi.org/10.1016/j.ijhydene.2015.01.073

[62] Pathak, P. Bhardwaj, N. and Singh, A. (2014) Production of Crude Cellulase and Xylanase from Trichoderma harzianum PPDDN10 NFCCI-2925 and Its Application in Photocopier Waste Paper Recycling. Applied Biochemistry and Biotechnology, 172, 3776-3797. http://dx.doi.org/10.1007/s12010-014-0758-9

[63] Singh, S., Tyagi, C.H., Dutt, D. and Upadhyaya, J.S. (2009) Production of High Level of Cellulase-Poor Xylanases by Wild Strains of White-Rot Fungus Coprinellus disseminatus in Solid-State Fermentation. New Biotechnology, 26, 165170. http://dx.doi.org/10.1016/j.nbt.2009.09.004 
[64] Dutt, D., Tyagi, C.H., Singh, R.P., Gautam, A., Agnohotri, S. and Kumar, A. (2013) Isolation and Biochemical Characterization of Crude Xylanase from Coprinus cinereus AT-1 MTCC 9695 and Its Effectiveness in Biodeinking of SOP. Cellulose Chemistry and Technology, 47, 203-217. http://www.cellulosechemtechnol.ro/pdf/CCT3-4(2013)/p.203-217.pdf

[65] Songulashvili, G., Spindler, D., Jimenéz-Tobón, G.A., Jaspers, C., Kerns, G. and Penninckx, M.J. (2015) Production of a High Level of Laccase by Submerged Fermentation at 120-L Scale of Cerrena unicolor C-139 Grown on Wheat Bran. Comptes Rendus Biologies, 338, 121-125. http://dx.doi.org/10.1016/j.crvi.2014.12.001

[66] Singh, S., Singh, S., Bali, V., Sharma, L. and Mangla, J. (2014) Production of Fungal Amylases Using Cheap, Readily Available Agriresidues, for Potential Application in Textile Industry. BioMed Research International, 2014, Article ID: 215748. http://dx.doi.org/10.1155/2014/215748

[67] Falony, G., Armas, J.C., Mendoza, J.C.D. and Martínez Hernández, J.L. (2006) Production of Extracellular Lipase from Aspergillus niger by Solid-State Fermentation. Food Technology and Biotechnology, 44, 235-240. http://www.ftb.com.hr/images/pdfarticles/2006/April-June/44-235.pdf

[68] Pan, C., Fan, Y. and Hou, H. (2008) Fermentative Production of Hydrogen from Wheat Bran by Mixed Anaerobic Cultures. Industrial \& Engineering Chemistry Research, 47, 5812-5818. http://dx.doi.org/10.1021/ie701789c

[69] Kalogeris, E., Iniotaki, F., Topakas, E., Christakopoulos, P., Kekos, D. and Macris, B.J. (2003) Performance of an Intermittent Agitation Rotating Drum Type Bioreactor for Solid-State Fermentation of Wheat Straw. Bioresource Technology, 86, 207-213. http://dx.doi.org/10.1016/S0960-8524(02)00175-X

[70] Qureshi, N., Saha, B.C. and Cotta, M.A. (2008) Butanol Production from Wheat Straw by Simultaneous Saccharification and Fermentation Using Clostridium beijerinckii: Part II-Fed-Batch Fermentation. Biomass and Bioenergy, 32, 176-183. http://dx.doi.org/10.1016/j.biombioe.2007.07.005

[71] Chandra, R., Takeuchi, H., Hasegawa, T. and Kumar, R. (2012) Improving Biodegradability and Biogas Production of Wheat Straw Substrates Using Sodium Hydroxide and Hydrothermal Pretreatments. Energy, 43, 273-282. http://dx.doi.org/10.1016/j.energy.2012.04.029

[72] Soni, R., Nazir, A. and Chadha, B.S. (2010) Optimization of Cellulase Production by a Versatile Aspergillus fumigatus Fresenius Strain (AMA) Capable of Efficient Deinking and Enzymatic Hydrolysis of Solka Floc and Bagasse. Industrial Crops and Products, 31, 277-283. http://dx.doi.org/10.1016/j.indcrop.2009.11.007

[73] Zhang, Q. and Cai, W. (2008) Enzymatic Hydrolysis of Alkali-Pretreated Rice Straw by Trichoderma reesei ZM4-F3. Biomass and Bioenergy, 32, 1130-1135. http://dx.doi.org/10.1016/j.biombioe.2008.02.006

[74] Rocky-Salimi, K. and Hamidi-Esfahani, Z. (2010) Evaluation of the Effect of Particle Size, Aeration Rate and Harvest Time on the Production of Cellulase by Trichoderma reesei QM9414 Using Response Surface Methodology. Food and Bioproducts Processing, 88, 61-66. http://dx.doi.org/10.1016/j.fbp.2009.06.006

[75] Melzoch, K., Votruba, J., Hábová, V. and Rychtera, M.R. (1997) Lactic Acid Production in a Cell Retention Continuous Culture Using Lignocellulosic Hydrolysate as a Substrate. Journal of Biotechnology, 56, 25-31. http://dx.doi.org/10.1016/S0168-1656(97)00074-6

[76] Singh, A., Bajar, S. and Bishnoi, N.R. (2014) Enzymatic Hydrolysis of Microwave Alkali Pretreated Rice Husk for Ethanol Production by Saccharomyces cerevisiae, Scheffersomyces stipitis and Their Co-Culture. Fuel, 116, 699-702. http://dx.doi.org/10.1016/j.fuel.2013.08.072

[77] Rambo, M.K.D., Bevilaqua, D.B., Brenner, C.G.B., Martins, A.F., Mario, D.N., Alves, S.H. and Mallmann, C.A. (2013) Xylitol from Rice Husks by Acid Hydrolysis and Candida Yeast Fermentation. Química Nova, 36, 634-639. http://dx.doi.org/10.1590/S0100-40422013000500004

[78] Xia, L.M. and Shen, X.L. (2004) High-Yield Cellulase Production by Trichoderma reesei ZU-02 on Corn Cob Residue. Bioresource Technology, 91, 259-262. http://dx.doi.org/10.1016/S0960-8524(03)00195-0

[79] Guo, X., Zhang, R., Li, Z., Dai, D., Li, C. and Zhou, X. (2013) A Novel Pathway Construction in Candida tropicalis for Direct Xylitol Conversion from Corncob Xylan. Bioresource Technology, 128, 547-552. http://dx.doi.org/10.1016/j.biortech.2012.10.155

[80] Panagiotopoulos, I.A., Bakker, R.R., de Vrije, T., Koukios, E.G. and Claassen, P.A.M. (2010) Pretreatment of Sweet Sorghum Bagasse for Hydrogen Production by Caldicellulosiruptor saccharolyticus. International Journal of Hydrogen Energy, 35, 7738-7747. http://dx.doi.org/10.1016/j.ijhydene.2010.05.075

[81] Mamma, D., Kourtoglou, E. and Christakopoulos, P. (2008) Fungal Multienzyme Production on Industrial By-Products of the Citrus-Processing Industry. Bioresource Technology, 99, 2373-2383. http://dx.doi.org/10.1016/j.biortech.2007.05.018

[82] Pan, C.-M., Ma, H.-C., Fan, Y.-T. and Hou, H.-W. (2011) Bioaugmented Cellulosic Hydrogen Production from Cornstalk by Integrating Dilute Acid-Enzyme Hydrolysis and Dark Fermentation. International Journal of Hydrogen Energy, 36, 4852-4862. http://dx.doi.org/10.1016/j.ijhydene.2011.01.114 
[83] Zhu, J., Wan, C. and Li, Y. (2010) Enhanced Solid-State Anaerobic Digestion of Corn Stover by Alkaline Pretreatment. Bioresource Technology, 101, 7523-7528. http://dx.doi.org/10.1016/j.biortech.2010.04.060

[84] Song, Z., Yang, G.H., Liu, X., Yan, Z., Yuan, Y. and Liao, Y. (2014) Comparison of Seven Chemical Pretreatments of Corn Straw for Improving Methane Yield by Anaerobic Digestion. PLoS ONE, 9, e93801. http://dx.doi.org/10.1371/journal.pone.0093801

[85] Mekala, N., Singhania, R., Sukumaran, R. and Pandey, A. (2008) Cellulase Production under Solid-State Fermentation by Trichoderma reesei RUT C30: Statistical Optimization of Process Parameters. Applied Biochemistry and Biotechnology, 151, 122-131. http://dx.doi.org/10.1007/s12010-008-8156-9

[86] Farinas, C.S., Vitcosque, G.L., Fonseca, R.F., Neto, V.B. and Couri, S. (2011) Modeling the Effects of Solid State Fermentation Operating Conditions on Endoglucanase Production Using an Instrumented Bioreactor. Industrial Crops and Products, 34, 1186-1192. http://dx.doi.org/10.1016/j.indcrop.2011.04.006

[87] Marques, S., Alves, L., Roseiro, J.C. and Gírio, F.M. (2008) Conversion of Recycled Paper Sludge to Ethanol by SHF and SSF Using Pichia stipitis. Biomass and Bioenergy, 32, 400-406. http://dx.doi.org/10.1016/j.biombioe.2007.10.011

[88] Budhavaram, N.K. and Fan, Z. (2009) Production of lactic acid from Paper Sludge Using Acid-Tolerant, Thermophilic Bacillus coagulan Strains. Bioresource Technology, 100, 5966-5972. http://dx.doi.org/10.1016/j.biortech.2009.01.080

[89] Lin, Y., Wang, D., Wu, S. and Wang, C. (2009) Alkali Pretreatment Enhances Biogas Production in the Anaerobic Digestion of Pulp and Paper Sludge. Journal of Hazardous Materials, 170, 366-373. http://dx.doi.org/10.1016/j.jhazmat.2009.04.086

[90] Sharma, S.K., Kalra, K.L. and Kocher, G.S. (2004) Fermentation of Enzymatic Hydrolysate of Sunflower Hulls for Ethanol Production and Its Scale-Up. Biomass and Bioenergy, 27, 399-402. http://dx.doi.org/10.1016/j.biombioe.2004.03.005

[91] Nigam, J.N. (2002) Bioconversion of Water-Hyacinth (Eichhornia crassipes) Hemicellulose Acid Hydrolysate to Motor Fuel Ethanol by Xylose-Fermenting Yeast. Journal of Biotechnology, 97, 107-116. http://dx.doi.org/10.1016/S0168-1656(02)00013-5

[92] Aswathy, U.S., Sukumaran, R.K., Devi, G.L., Rajasree, K.P., Singhania, R.R. and Pandey, A. (2010) Bio-Ethanol from Water Hyacinth Biomass: An Evaluation of Enzymatic Saccharification Strategy. Bioresource Technology, 101, 925930. http://dx.doi.org/10.1016/j.biortech.2009.08.019

[93] Chandel, A.K., Antunes, F.A.F., de Arruda, P.V., Milessi, T.S.S., da Silva, S.S. and Felipe, M. das G. de A. (2012) Dilute Acid Hydrolysis of Agro-Residues for the Depolymerization of Hemicellulose: State-of-the-Art. In: da Silva, S.S. and Chandel, A.K., Eds., D-Xylitol, Springer Berlin Heidelberg, 39-61.

[94] Chandel, A.K., da Silva, S.S., Carvalho, W. and Singh, O.V. (2012) Sugarcane Bagasse and Leaves: Foreseeable Biomass of Biofuel and Bio-Products. Journal of Chemical Technology \& Biotechnology, 87, 11-20. http://dx.doi.org/10.1002/jctb.2742

[95] EIA (2013) International Energy Outlook 2013. U.S. Energy Information Administration, DOE/EIA-0484 (2013). http://www.eia.gov/forecasts/ieo/pdf/0484(2013).pdf

[96] Garoma, T. and Shackelford, T. (2014) Electroporation of Chlorella vulgaris to Enhance Biomethane Production. Bioresource Technology, 169, 778-783. http://dx.doi.org/10.1016/j.biortech.2014.07.001

[97] Chandel, A.K., Singh, O.V., Venkateswar Rao, L., Chandrasekhar, G. and Lakshmi Narasu, M. (2011) Bioconversion of Novel Substrate Saccharum spontaneum, a Weedy Material, into Ethanol by Pichia stipitis NCIM3498. Bioresource Technology, 102, 1709-1714. http://dx.doi.org/10.1016/j.biortech.2010.08.016

[98] Kerr, R.A. and Service, R.F. (2005) What Can Replace Cheap Oil—and When? Science, 309, 101. http://dx.doi.org/10.1126/science.309.5731.101

[99] Agbor, V.B., Cicek, N., Sparling, R., Berlin, A. and Levin, D.B. (2011) Biomass Pretreatment: Fundamentals toward Application. Biotechnology Advances, 29, 675-685. http://dx.doi.org/10.1016/j.biotechadv.2011.05.005

[100] Gil, N., Ferreira, S., Amaral, M.E., Domingues, F.C. and Duarte, A.P. (2010) The Influence of Dilute Acid Pretreatment Conditions on the Enzymatic Saccharification of Erica spp. for Bioethanol Production. Industrial Crops and Products, 32, 29-35. http://dx.doi.org/10.1016/j.indcrop.2010.02.013

[101] Gupta, A. and Verma, J.P. (2015) Sustainable Bio-Ethanol Production from Agro-Residues: A Review. Renewable and Sustainable Energy Reviews, 41, 550-567. http://dx.doi.org/10.1016/j.rser.2014.08.032

[102] Nikolic, S., Mojovic, L., Rakin, M. and Pejin, D. (2009) Bioethanol Production from Corn Meal by Simultaneous Enzymatic Saccharification and Fermentation with Immobilized Cells of Saccharomyces cerevisiae var. ellipsoideus. Fuel, 88, 1602-1607. http://dx.doi.org/10.1016/j.fuel.2008.12.019

[103] Guimaraes, P.M.R., Teixeira, J.A. and Domingues, L. (2010) Fermentation of Lactose to Bio-Ethanol by Yeasts as Part of Integrated Solutions for the Valorisation of Cheese Whey. Biotechnology Advances, 28, 375-384. http://dx.doi.org/10.1016/j.biotechadv.2010.02.002 
[104] Watanabe, I., Nakamura, T. and Shima, J. (2009) Characterization of a Spontaneous Flocculation Mutant Derived from Candida glabrata: A Useful Strain for Bioethanol Production. Journal of Bioscience and Bioengineering, 107, 379-382. http://dx.doi.org/10.1016/j.jbiosc.2008.12.002

[105] Das, A., Paul, T., Jana, A., Halder, S.K., Ghosh, K., Maity, C., Mohapatra, P.K.D., Pati, B.R. and Mondal, K.C. (2013) Bioconversion of Rice Straw to Sugar Using Multizyme Complex of Fungal Origin and Subsequent Production of Bioethanol by Mixed Fermentation of Saccharomyces cerevisiae MTCC 173 and Zymomonas mobilis MTCC 2428. Industrial Crops and Products, 46, 217-225. http://dx.doi.org/10.1016/j.indcrop.2013.02.003

[106] Boluda-Aguilar, M. and Lopez-Gomez, A. (2013) Production of Bioethanol by Fermentation of Lemon (Citrus limon L.) Peel Wastes Pretreated with Steam Explosion. Industrial Crops and Products, 41, 188-197. http://dx.doi.org/10.1016/j.indcrop.2012.04.031

[107] Whitfield, M.B., Chinn, M.S. and Veal, M.W. (2012) Processing of Materials Derived from Sweet Sorghum for Biobased Products. Industrial Crops and Products, 37, 362-375. http://dx.doi.org/10.1016/j.indcrop.2011.12.011

[108] Sukumaran, R.K., Singhania, R.R., Mathew, G.M. and Pandey, A. (2009) Cellulase Production Using Biomass Feed Stock and Its Application in Lignocellulose Saccharification for Bio-Ethanol Production. Renewable Energy, 34, 421-424. http://dx.doi.org/10.1016/j.renene.2008.05.008

[109] Roberto, I.S.C., Mussatto, S.I. and Rodrigues, R.C.L.B. (2003) Dilute-Acid Hydrolysis for Optimization of Xylose Recovery from Rice Straw in a Semi-Pilot Reactor. Industrial Crops and Products, 17, 171-176. http://dx.doi.org/10.1016/S0926-6690(02)00095-X

[110] Karim, R., Hussain, A. and Mohd Zain, A. (2014) Production of Bioethanol from Empty Fruit Bunches Cellulosic Biomass and Avicel PH-101 Cellulose. Biomass Conversion and Biorefinery, 4, 333-340. http://dx.doi.org/10.1007/s13399-014-0117-7

[111] Al-Shorgani, N.K.N., Shukor, H., Abdeshahian, P., Mohd Nazir, M.Y., Kalil, M.S., Hamid, A.A. and Wan Yusoff, W.M. (2015) Process Optimization of Butanol Production by Clostridium saccharoperbutylacetonicum N1-4 (ATCC 13564) Using Palm Oil Mill Effluent in Acetone-Butanol-Ethanol Fermentation. Biocatalysis and Agricultural Biotechnology, 4, 244-249. http://dx.doi.org/10.1016/j.bcab.2015.02.004

[112] Al-Shorgani, N.K., Abdul Hamid, A., Wan Yusoff, W.M and Kalil, M.S. (2013) Pre-Optimization of Medium for Biobutanol Production by a New Isolate of Solvent-Producing Clostridium. BioResources, 8, 1420-1430. http://dx.doi.org/10.15376/biores.8.1.1420-1430

[113] Green, E.M. (2011) Fermentative Production of Butanol-The Industrial Perspective. Current Opinion in Biotechnology, 22, 337-343. http://dx.doi.org/10.1016/j.copbio.2011.02.004

[114] Zheng, J., Tashiro, Y., Wang, Q. and Sonomoto, K. (2015) Recent Advances to Improve Fermentative Butanol Production: Genetic Engineering and Fermentation Technology. Journal of Bioscience and Bioengineering, 119, 1-9. http://dx.doi.org/10.1016/j.jbiosc.2014.05.023

[115] Chen, W.-H., Chen, Y.-C. and Lin, J.-G. (2013) Evaluation of Biobutanol Production from Non-Pretreated Rice Straw Hydrolysate under Non-Sterile Environmental Conditions. Bioresource Technology, 135, 262-268. http://dx.doi.org/10.1016/j.biortech.2012.10.140

[116] Shukor, H., Al-Shorgani, N.K., Abdeshahian, N.P., Hamid, A.A., Anuar, N., Rahman, N.A. and Kalil, M.S. (2014) Production of Butanol by Clostridium saccharoperbutylacetonicum N1-4 from Palm Kernel Cake in Acetone-ButanolEthanol Fermentation Using an Empirical Model. Bioresource Technology, 170, 565-573. http://dx.doi.org/10.1016/j.biortech.2014.07.055

[117] Mayer, F., Gerin, P.A., Noo, A., Foucart, G., Flammang, J., Lemaigre, S., Sinnaeve, G., Dardenne, P. and Delfosse, P. (2014) Assessment of Factors Influencing the Biomethane Yield of Maize Silages. Bioresource Technology, 153, 260-268. http://dx.doi.org/10.1016/j.biortech.2013.11.081

[118] Zheng, Y., Zhao, J., Xu, F. and Li, Y. (2014) Pretreatment of Lignocellulosic Biomass for Enhanced Biogas Production. Progress in Energy and Combustion Science, 42, 35-53. http://dx.doi.org/10.1016/j.pecs.2014.01.001

[119] Patterson, T., Esteves, S., Dinsdale, R., Guwy, A. and Maddy, J. (2013) Life Cycle Assessment of Biohydrogen and Biomethane Production and Utilisation as a Vehicle Fuel. Bioresource Technology, 131, 235-245. http://dx.doi.org/10.1016/j.biortech.2012.12.109

[120] Seppala, M., Pyykkönen, V., Väisänen, A. and Rintala, J. (2013) Biomethane Production from Maize and Liquid Cow Manure-Effect of Share of Maize, Post-Methanation Potential and Digestate Characteristics. Fuel, 107, 209-216. http://dx.doi.org/10.1016/j.fuel.2012.12.069

[121] El-Mashad, H.M. (2015) Biomethane and Ethanol Production Potential of Spirulina platensis Algae and Enzymatically Saccharified Switchgrass. Biochemical Engineering Journal, 93, 119-127. http://dx.doi.org/10.1016/j.bej.2014.09.009

[122] Antoni, D., Zverlov, V. and Schwarz, W. (2007) Biofuels from Microbes. Applied Microbiology and Biotechnology, 77, 23-35. http://dx.doi.org/10.1007/s00253-007-1163-X 
[123] Sambusiti, C., Monlau, F., Ficara, E., Carrère, H. and Malpei, F. (2013) A Comparison of Different Pre-Treatments to Increase Methane Production from Two Agricultural Substrates. Applied Energy, 104, 62-70. http://dx.doi.org/10.1016/j.apenergy.2012.10.060

[124] Mirahmadi, K., Mohseni Kabir, M., Jeihanipour, A., Karimi, K. and Taherzadeh, M. (2010) Alkaline Pretreatment of Spruce and Birch to Improve Bioethanol and Biogas Production. BioResources, 5, 928-938.

[125] Zheng, M., Li, X., Li, L., Yang, X. and He, Y. (2009) Enhancing Anaerobic Biogasification of Corn Stover through Wet State NaOH Pretreatment. Bioresource Technology, 100, 5140-5145. http://dx.doi.org/10.1016/j.biortech.2009.05.045

[126] Liew, L.N., Shi, J. and Li, Y. (2011) Enhancing the Solid-State Anaerobic Digestion of Fallen Leaves through Simultaneous Alkaline Treatment. Bioresource Technology, 102, 8828-8834. http://dx.doi.org/10.1016/j.biortech.2011.07.005

[127] Sigurbjornsdottir, M.A. and Orlygsson, J. (2012) Combined Hydrogen and Ethanol Production from Sugars and Lignocellulosic Biomass by Thermoanaerobacterium $\mathrm{AK}_{54}$, Isolated from Hot Spring. Applied Energy, 97, 785-791. http://dx.doi.org/10.1016/j.apenergy.2011.11.035

[128] Ren, N., Wang, A., Cao, G., Xu, J. and Gao L. (2009) Bioconversion of Lignocellulosic Biomass to Hydrogen: Potential and Challenges. Biotechnology Advances, 27, 1051-1060. http://dx.doi.org/10.1016/j.biotechadv.2009.05.007

[129] Song, Z.-X., Dai, Y., Fan, Q.-L., Li, X.-H., Fan, Y.-T. and Hou, H.-W. (2012) Effects of Pretreatment Method of Natural Bacteria Source on Microbial Community and Bio-Hydrogen Production by Dark Fermentation. International Journal of Hydrogen Energy, 37, 5631-5636. http://dx.doi.org/10.1016/j.ijhydene.2012.01.010

[130] Chen, C.C., Lin, C.Y. and Chang, J.S. (2001) Kinetics of Hydrogen Production with Continuous Anaerobic Cultures Utilizing Sucrose as the Limiting Substrate. Applied Microbiology and Biotechnology, 57, 56-64. http://dx.doi.org/10.1007/s002530100747

[131] Kumar, N. and Das, D. (2001) Continuous Hydrogen Production by Immobilized Enterobacter cloacae IIT-BT 08 Using Lignocellulosic Materials as Solid Matrices. Enzyme and Microbial Technology, 29, 280-287. http://dx.doi.org/10.1016/S0141-0229(01)00394-5

[132] Xing, D., Ren, N., Li, Q., Lin, M., Wang, A. and Zhao, L. (2006) Ethanoligenens harbinense gen. nov., sp. nov., Isolated from Molasses Wastewater. International Journal of Systematic and Evolutionary Microbiology, 56, 755-760. http://dx.doi.org/10.1099/ijs.0.63926-0

[133] van Niel, E.W.J, Budde, M.A.W., de Haas, G.G., van der Wal, F.J., Claassen, P.A.M. and Stams, A.J.M. (2002) Distinctive Properties of High Hydrogen Producing Extreme Thermophiles, Caldicellulosiruptor saccharolyticus and Thermotoga elfii. International Journal of Hydrogen Energy, 27, 1391-1398. http://dx.doi.org/10.1016/S0360-3199(02)00115-5

[134] Lu, Y., Zhang, W.D., Song, H.C., Li, J.C. and Xia, C.F. (2003) Research on Potential of the Hydrogen Fermentation with Pig Dung. Energy Engineering, 2, 26.

[135] Fan, L.T., Lee, Y.-H. and Gharpuray, M.M. (1982) The Nature of Lignocellulosics and Their Pretreatments for Enzymatic Hydrolysis. In: Advances in Biochemical Engineering, Springer Berlin Heidelberg, 157-187.

[136] Tang, X.X., Ren, N.Q. and Xu, J.F. (2013) Evaluation of Hydrogen Production from Corn Cob with the Mesophilic Bacterium Clostridium hydrogeniproducens HR-1. International Journal of Hydrogen Energy, 38, 9104-9110. http://dx.doi.org/10.1016/j.ijhydene.2013.05.066

[137] Sauer, M., Porro, D., Mattanovich, D. and Branduardi, P. (2008) Microbial Production of Organic Acids: Expanding the Markets. Trends in Biotechnology, 26, 100-108. http://dx.doi.org/10.1016/j.tibtech.2007.11.006

[138] Dhillon, G.S., Brar, S.K., Kaur, S. and Verma, M. (2013) Bioproduction and Extraction Optimization of Citric Acid from Aspergillus niger by Rotating Drum Type Solid-State Bioreactor. Industrial Crops and Products, 41, 78-84. http://dx.doi.org/10.1016/j.indcrop.2012.04.001

[139] Prado, F.C., Vandenberghe, L.P.S., Woiciechowski, A.L., Rodrígues-León, J.A. and Soccol, C.R. (2005) Citric Acid Production by Solid-State Fermentation on a Semi-Pilot Scale Using Different Percentages of Treated Cassava Bagasse. Brazilian Journal of Chemical Engineering, 22, 547-555. http://dx.doi.org/10.1590/S0104-66322005000400007

[140] Sharma, A., Vivekanand, V. and Singh, R.P. (2008) Solid-State Fermentation for Gluconic Acid Production from Sugarcane Molasses by Aspergillus niger ARNU-4 Employing Tea Waste as the Novel Solid Support. Bioresource Technology, 99, 3444-3450. http://dx.doi.org/10.1016/j.biortech.2007.08.006

[141] Dhillon, G.S., Brar, S.K., Verma, M. and Tyagi, R.D. (2011) Recent Advances in Citric Acid Bio-Production and Recovery. Food and Bioprocess Technology, 4, 505-529. http://dx.doi.org/10.1007/s11947-010-0399-0

[142] Prado, F.C., de Souza Vandenberghe, L.P. and Soccol, C.R. (2005) Relation between Citric Acid Production by Solid-State Fermentation from Cassava Bagasse and Respiration of Aspergillus niger LPB 21 in Semi-Pilot Scale. Brazilian Archives of Biology and Technology, 48, 29-36. http://dx.doi.org/10.1590/S1516-89132005000400004 
[143] Papagianni, M. (2007) Advances in Citric Acid Fermentation by Aspergillus niger: Biochemical Aspects, Membrane Transport and Modeling. Biotechnology Advances, 25, 244-263. http://dx.doi.org/10.1016/j.biotechadv.2007.01.002

[144] Torrado, A.M., Cortés, S., Salgado, J.M., Max, B., Rodríguez, N., Bibbins, B.P., Converti, A. and Domínguez, J.M. (2011) Citric Acid Production from Orange Peel Wastes by Solid-State Fermentation. Brazilian Journal of Microbiology, 42, 394-409. http://dx.doi.org/10.1590/S1517-83822011000100049

[145] Bari, M.N., Alam, M.Z., Muyibi, S.A., Jamal, P. and Abdullah Al, M. (2009) Improvement of Production of Citric Acid from Oil Palm Empty Fruit Bunches: Optimization of Media by Statistical Experimental Designs. Bioresource Technology, 100, 3113-3120. http://dx.doi.org/10.1016/j.biortech.2009.01.005

[146] Shojaosadati, S.A. and Babaeipour, V. (2002) Citric Acid Production from Apple Pomace in Multi-Layer Packed Bed Solid-State Bioreactor. Process Biochemistry, 37, 909-914. http://dx.doi.org/10.1016/S0032-9592(01)00294-1

[147] Kiel, H., Guvrin, R. and Henis, Y. (1981) Citric Acid Fermentation by Aspergillus niger on Low Sugar Concentrations and Cotton Waste. Applied and Environmental Microbiology, 42, 1-4. http://www.ncbi.nlm.nih.gov/pubmed/16345802

[148] Hang, Y.D. and Woodams, E.E. (1998) Production of Citric Acid from Corncobs by Aspergillus niger. Bioresource Technology, 65, 251-253. http://dx.doi.org/10.1016/S0960-8524(98)00015-7

[149] Hang, Y.D. and Woodams, E.E. (2000) Corn Husks: A Potential Substrate for Production of Citric Acid by Aspergillus niger. LWT-Food Science and Technology, 33, 520-521. http://dx.doi.org/10.1006/fstl.2000.0711

[150] Tran, C.T., Sly, L.I. and Mitchell, D.A. (1998) Selection of a Strain of Aspergillus for the Production of Citric Acid from Pineapple Waste in Solid-State Fermentation. World Journal of Microbiology and Biotechnology, 14, 399-404. http://link.springer.com/article/10.1023\%2FA\%3A1008821413239 http://dx.doi.org/10.1023/A:1008821413239

[151] Wang, D., Li, Q., Yang, M., Zhang, Y., Su, Z. and Xing, J. (2011) Efficient Production of Succinic Acid from Corn Stalk Hydrolysates by a Recombinant Escherichia coli with ptsG Mutation. Process Biochemistry, 46, 365-371. http://dx.doi.org/10.1016/j.procbio.2010.09.012

[152] Liu, R., Liang, L., Li, F., Wu, M., Chen, K., Ma, J., Jiang, M., Wei, P. and Ouyang, P. (2013) Efficient Succinic Acid Production from Lignocellulosic Biomass by Simultaneous Utilization of Glucose and Xylose in Engineered Escherichia coli. Bioresource Technology, 149, 84-91. http://dx.doi.org/10.1016/j.biortech.2013.09.052

[153] Zheng, P., Fang, L., Xu, Y., Dong, J.-J., Ni, Y. and Sun, Z.-H. (2010) Succinic Acid Production from Corn Stover by Simultaneous Saccharification and Fermentation Using Actinobacillus succinogenes. Bioresource Technology, 101, 7889-7894. http://dx.doi.org/10.1016/j.biortech.2010.05.016

[154] Bao, H., Liu, R., Liang, L., Jiang, Y., Jiang, M., Ma, J., Chen, K., Jia, H., Wei, P. and Ouyang, P. (2014) Succinic Acid Production from Hemicellulose Hydrolysate by an Escherichia coli Mutant Obtained by Atmospheric and Room Temperature Plasma and Adaptive Evolution. Enzyme and Microbial Technology, 66, 10-15. http://dx.doi.org/10.1016/j.enzmictec.2014.04.017

[155] Kim, D.Y., Yim, S.C., Lee, P.C., Lee, W.G., Lee, S.Y. and Chang, H.N. (2004) Batch and Continuous Fermentation of Succinic Acid from Wood Hydrolysate by Mannheimia succiniciproducens MBEL55E. Enzyme and Microbial Technology, 35, 648-653. http://dx.doi.org/10.1016/j.enzmictec.2004.08.018

[156] Wang, C., Yan, D., Li, Q., Sun, W. and Xing, J. (2014) Ionic Liquid Pretreatment to Increase Succinic Acid Production from Lignocellulosic Biomass. Bioresource Technology, 172, 283-289. http://dx.doi.org/10.1016/j.biortech.2014.09.045

[157] Gunnarsson, I.B., Kuglarz, M., Karakashev, D. and Angelidaki, I. (2015) Thermochemical Pretreatments for Enhancing Succinic Acid Production from Industrial Hemp (Cannabis sativa L.). Bioresource Technology, 182, 58-66. http://dx.doi.org/10.1016/j.biortech.2015.01.126

[158] Cheng, K.-K., Wu, J., Wang, G.-Y., Li, W.-Y., Feng, J. and Zhang, J.-A. (2013) Effects of pH and Dissolved CO ${ }_{2}$ Lev- $^{-}$ el on Simultaneous Production of 2,3-Butanediol and Succinic Acid Using Klebsiella pneumoniae. Bioresource Technology, 135, 500-503. http://dx.doi.org/10.1016/j.biortech.2012.08.100

[159] Yan, D., Wang, C., Zhou, J., Liu, Y., Yang, M. and Xing, J. (2014) Construction of Reductive Pathway in Saccharomyces cerevisiae for Effective Succinic Acid Fermentation at Low pH Value. Bioresource Technology, 156, $232-239$. http://dx.doi.org/10.1016/j.biortech.2014.01.053

[160] Wee, Y.-J. and Ryu, H.-W. (2009) Lactic Acid Production by Lactobacillus sp. RKY2 in a Cell-Recycle Continuous Fermentation Using Lignocellulosic Hydrolyzates as Inexpensive Raw Materials. Bioresource Technology, 100, 42624270. http://dx.doi.org/10.1016/j.biortech.2009.03.074

[161] Zhang, Y. and Vadlani, P.V. (2015) Lactic Acid Production from Biomass-Derived Sugars via Co-Fermentation of Lactobacillus brevis and Lactobacillus plantarum. Journal of Bioscience and Bioengineering, 119, 694-699. http://dx.doi.org/10.1016/j.jbiosc.2014.10.027

[162] Hu, J., Zhang, Z., Lin, Y., Zhao, S., Mei, Y., Liang, Y. and Peng, N. (2015) High-Titer Lactic Acid Production from $\mathrm{NaOH}-$ Pretreated Corn Stover by Bacillus coagulans LA204 Using Fed-Batch Simultaneous Saccharification and 
Fermentation under Non-Sterile Condition. Bioresource Technology, 182, 251-257. http://dx.doi.org/10.1016/j.biortech.2015.02.008

[163] Abdel-Rahman, M.A., Tashiro, Y. and Sonomoto, K. (2011) Lactic Acid Production from Lignocellulose-Derived Sugars Using Lactic Acid Bacteria: Overview and Limits. Journal of Biotechnology, 156, 286-301. http://dx.doi.org/10.1016/j.jbiotec.2011.06.017

[164] Ouyang, J., Ma, R., Zheng, Z., Cai, C., Zhang, M. and Jiang, T. (2013) Open Fermentative Production of ${ }_{\text {L }}$-Lactic Acid by Bacillus sp. Strain NL01 Using Lignocellulosic Hydrolyzates as Low-Cost Raw Material. Bioresource Technology, 135, 475-480. http://dx.doi.org/10.1016/j.biortech.2012.09.096

[165] Gao, M.-T., Kaneko, M., Hirata, M., Toorisaka, E. and Hano, T. (2008) Utilization of Rice Bran as Nutrient Source for Fermentative Lactic Acid Production. Bioresource Technology, 99, 3659-3664. http://dx.doi.org/10.1016/j.biortech.2007.07.025

[166] Guo, W., Jia, W., Li, Y. and Chen, S. (2010) Performances of Lactobacillus brevis for Producing Lactic Acid from Hydrolysate of Lignocellulosics. Applied Biochemistry and Biotechnology, 161, 124-136. http://dx.doi.org/10.1007/s12010-009-8857-8

[167] Xavier, S. and Lonsane, B.K. (1994) Sugar-Cane Pressmud as a Novel and Inexpensive Substrate for Production of Lactic Acid in a Solid-State Fermentation System. Applied Microbiology and Biotechnology, 41, 291-295. http://dx.doi.org/10.1007/BF00221221

[168] Patel, M., Ou, M., Ingram, L.O. and Shanmugam, K.T. (2004) Fermentation of Sugar Cane Bagasse Hemicellulose Hydrolysate to l(+)-Lactic Acid by a Thermotolerant Acidophilic Bacillus sp. Biotechnology Letters, 26, 865-868. http://dx.doi.org/10.1023/B:bile.0000025893.27700.5c

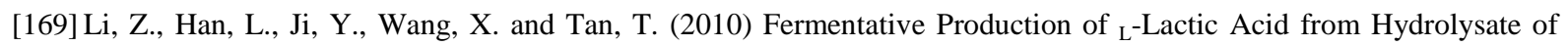
Wheat Bran by Lactobacillus rhamnosus. Biochemical Engineering Journal, 49, 138-142. http://dx.doi.org/10.1016/j.bej.2009.10.014

[170] Gao, C., Ma, C. and Xu, P. (2011) Biotechnological Routes Based on Lactic Acid Production from Biomass. Biotechnology Advances, 29, 930-939. http://dx.doi.org/10.1016/j.biotechadv.2011.07.022

[171] Park, E.Y., Anh, P.N. and Okuda, N. (2004) Bioconversion of Waste Office Paper to ${ }_{\text {L }}+$ )-Lactic Acid by the Filamentous Fungus Rhizopus oryzae. Bioresource Technology, 93, 77-83. http://dx.doi.org/10.1016/j.biortech.2003.08.017

[172] Yáñez, R., Belén Moldes, A., Alonso, J. and Parajo, J. (2003) Production of D(-)-Lactic Acid from Cellulose by Simultaneous Saccharification and Fermentation Using Lactobacillus coryniformis subsp. torquens. Biotechnology Letters, 25, 1161-1164. http://dx.doi.org/10.1023/A:1024534106483

[173] Hofvendahl, K. and Hahn-Hägerdal, B. (2000) Factors Affecting the Fermentative Lactic Acid Production from Renewable Resources. Enzyme and Microbial Technology, 26, 87-107. http://dx.doi.org/10.1016/S0141-0229(99)00155-6

[174] Rackemann, D.W. and Doherty, W.O.S. (2011) The Conversion of Lignocellulosics to Levulinic Acid. Biofuels, Bioproducts and Biorefining, 5, 198-214. http://dx.doi.org/10.1002/bbb.267

[175] Weingarten, R., Conner, W.C. and Huber, G.W. (2012) Production of Levulinic Acid from Cellulose by Hydrothermal Decomposition Combined with Aqueous Phase Dehydration with a Solid Acid Catalyst. Energy \& Environmental Science, 5, 7559-7574. http://dx.doi.org/10.1039/c2ee21593d

[176] Jahan, M.S., Chowdhury, D.A.N. and Islam, M.K. (2007) Atmospheric Formic Acid Pulping and TCF Bleaching of Dhaincha (Sesbania aculeata), Kash (Saccharum spontaneum) and Banana Stem (Musa Cavendish). Industrial Crops and Products, 26, 324-331. http://dx.doi.org/10.1016/j.indcrop.2007.03.012

[177] Jahan, M.S., Saeed, A., He, Z. and Ni, Y. (2011) Jute as Raw Material for the Preparation of Microcrystalline Cellulose. Cellulose, 18, 451-459. http://dx.doi.org/10.1007/s10570-010-9481-z

[178] Jahan, M.S., Chowdhury, D.N., Islam, M.K. and Islam, M.S. (2007) Organic Acid Pulping of Jute and Its Mechanism. Cellulose Chemistry and Technology, 41, 137-147.

[179] Jayakumar, G.C., Kanth, S.V., Chandrasekaran, B., Rao, J.R. and Nair, B.U. (2010) Preparation and Antimicrobial Activity of Scleraldehyde from Schizophyllum commune. Carbohydrate Research, 345, 2213-2219. http://dx.doi.org/10.1016/j.carres.2010.07.041

[180] Oner, E.T. (2013) Pretreatment Techniques for Biofuels and Biorefineries. Springer Berlin Heidelberg.

[181] Shu, C.-H. and Hsu, H.-J. (2011) Production of Schizophyllan Glucan by Schizophyllum commune ATCC 38548 from Detoxificated Hydrolysate of Rice Hull. Journal of the Taiwan Institute of Chemical Engineers, 42, 387-393. http://dx.doi.org/10.1016/j.jtice.2010.08.009

[182] Wang, D., Ju, X., Zhou, D. and Wei, G. (2014) Efficient Production of Pullulan Using Rice Hull Hydrolysate by Adaptive Laboratory Evolution of Aureobasidium pullulans. Bioresource Technology, 164, 12-19. http://dx.doi.org/10.1016/j.biortech.2014.04.036 
[183] Sheng, L., Zhu, G. and Tong, Q. (2013) Mechanism Study of Tween 80 Enhancing the Pullulan Production by Aureobasidium pullulans. Carbohydrate Polymers, 97, 121-123. http://dx.doi.org/10.1016/j.carbpol.2013.04.058

[184] Sugumaran, K.R., Gowthami, E., Swathi, B., Elakkiya, S., Srivastava, S.N., Ravikumar, R., Gowdhaman, D. and Ponnusami, V. (2013) Production of Pullulan by Aureobasidium pullulans from Asian Palm Kernel: A Novel Substrate. Carbohydrate Polymers, 92, 697-703. http://dx.doi.org/10.1016/j.carbpol.2012.09.062

[185] Psomas, S.K., Liakopoulou-Kyriakides, M. and Kyriakidis, D.A. (2007) Optimization Study of Xanthan Gum Production Using Response Surface Methodology. Biochemical Engineering Journal, 35, 273-280. http://dx.doi.org/10.1016/j.bej.2007.01.036

[186] Moreno, J., López, M.J., Vargas-García, C. and Vázquez, R. (1998) Use of Agricultural Wastes for Xanthan Production by Xanthomonas campestris. Journal of Industrial Microbiology and Biotechnology, 21, 242-246. http://dx.doi.org/10.1038/sj.jim.2900582

[187] Mondal, A.K., Sengupta, S., Bhowal, J. and Bhattacharya, D.K. (2012) Utilization of Fruit Wastes in Producing Single Cell Protein. International Journal of Science, Environment and Technology, 1, 430-438.

[188] Tesfaw, A. and Assefa, F. (2014) Co-Culture: A Great Promising Method in Single Cell Protein Production. Biotechnology and Molecular Biology Reviews, 9, 12-20. http://dx.doi.org/10.5897/BMBR2014.0223

[189] Yousufi, M.K. (2012) To Determine Protein Content of Single Cell Protein Produced by Using Various Combinations of Fruit Wastes and Two Standard Food Fungi. International Journal of Advanced Biotechnology and Research, 3, 533-536. http://bipublication.com/files/IJABR-V3I1-2012-08.pdf

[190] Jaganmohan, P., Daas, B.P. and Prasad, S.V. (2013) Production of Single Cell Protein (SCP) with Aspergillus terreus Using Solid State Fermentation. European Journal of Biological Sciences, 5, 38-43.

[191] Essien, J.P., Akpan, E.J. and Essien, E.P. (2005) Studies on Mould Growth and Biomass Production Using Waste Banana Peel. Bioresource Technology, 96, 1451-1456. http://dx.doi.org/10.1016/j.biortech.2004.12.004

[192] Leathers, T.D. (2003) Bioconversions of Maize Residues to Value-Added Coproducts Using Yeast-Like Fungi. FEMS Yeast Research, 3, 133-140. http://dx.doi.org/10.1016/S1567-1356(03)00003-5

[193] Rafqul, I.S.M. and Mimi Sakinah, A.M. (2012) A Perspective: Bioproduction of Xylitol by Enzyme Technology and Future Prospects. International Food Research Journal, 19, 405-408.

[194] Rao, R.S., Jyothi, C.P. and Rao, L.V. (2008) Biotechnological Production of Xylitol by Mutant Candida tropicalis OMV5: Process Optimization Using Statistical Approach. Indian Journal of Biotechnology, 7, 218-224. http://nopr.niscair.res.in/bitstream/123456789/1832/1/IJBT\%207\%282\%29\%20218-224.pdf

[195] Guo, C., Zhao, C., He, P., Lu, D., Shen, A. and Jiang, N. (2006) Screening and Characterization of Yeasts for Xylitol Production. Journal of Applied Microbiology, 101, 1096-1104. http://dx.doi.org/10.1111/j.1365-2672.2006.02994.x

\title{
Abbreviations
}

\author{
ABE-Acetone-butanol-ethanol \\ Btu-British thermal unit \\ CMCase-Carboxymethyl cellulase activity \\ FPase-Filter paper activity \\ FPU-Filter paper unit \\ G-Gram \\ Gds-Gram dry substrate \\ IU-International unit \\ Kg-Kilogram \\ L-Litre \\ MJ-Mega joule \\ M-Meter \\ $\mathrm{N}$ ml-normalized $\mathrm{ml}$ \\ SSF-Solis-state fermentation \\ TS-Total solids \\ TVS-Total volatile solids \\ VL_-Volatile solids
}

